\title{
Ion Recognition Approach to Volume Reduction of Alkaline Tank Waste by Separation of Sodium Salts
}

FY 2004 Annual Report, Environmental Management Science Program, Project \#81935

\author{
Bruce A. Moyer, Peter V. Bonnesen, Jeffrey C. Bryan, Radu Custelcean, Lætitia H. Delmau, \\ Nancy L. Engle, Hyun-Ah Kang, Tamara J. Keever, and Leon Maya \\ Chemical Sciences Division, Oak Ridge National Laboratory, P.O. Box 2008, Oak Ridge, TN \\ 37830-6119 \\ Alan P. Marchand, Srinivas Gadthula, Vinayak K. Gore, Zilin Huang, Rasapalli Sivappa, and \\ Pavan K. Tirunahari \\ Department of Chemistry, University of North Texas, NT Station, Box 305070, Denton, TX \\ 76203-5070 \\ Tatiana G. Levitskaia and Gregg J. Lumetta \\ Radiochemical Science and Engineering Group, Pacific Northwest National Laboratory, P.O. \\ Box 999; MSIN P7-22, Richland, WA 99352
}

June 30, 2004

This research was sponsored by the Environmental Management Science Program of the Office of Science, U. S. Department of Energy, under a) Contract Number DE-AC05-00OR22725 with Oak Ridge National Laboratory, managed and operated by UT-Battelle, LLC; b) Contract Number DE-AC06-76RLO-1830 with Pacific Northwest National Laboratory, managed and operated by Battelle Memorial Institute; and c) Grant Number DE-FG07-98ER14936 with the University of North Texas. Any opinions, findings, conclusions, or recommendations expressed herein are those of the authors and do not necessarily reflect the views of DOE. Support for H.A.K. under the Postdoctoral Fellowship Program of Korea Science \& Engineering Foundation (KOSEF) is gratefully acknowledged; the participation of H.-A.K. was made possible by an appointment to the Oak Ridge National Laboratory Postgraduate Program administered by the Oak Ridge Associated Universities. 


\title{
ANNUAL PROGRESS REPORT
}

\author{
U.S. Department of Energy
}

\section{Ion Recognition Approach to Volume Reduction of Alkaline Tank Waste by Separation of Sodium Salts}

Principle Investigator: Bruce A. Moyer ${ }^{1}$

Co-investigators: $\quad$ Peter V. Bonnesen, ${ }^{1}$ Gregg J. Lumetta, ${ }^{2}$ and Alan P. Marchand ${ }^{3}$

${ }^{1}$ Chemical Separations Group, Chemical Sciences Division, Oak Ridge National Laboratory, P.O. Box 2008, Bldg. 4500S, Oak Ridge, TN 37831-6119. Phone: 865-574-6718. Fax: 865-5744939. E-mail: moyerba@ornl.gov

${ }^{2}$ Radiochemical Science and Engineering Group, Pacific Northwest National Laboratory, P.O. Box 999; MSIN P7-22, Richland, WA 99352. Phone: 509-376-6911. Fax: 509-373-9675. E-mail: gregg.lumetta@pnl.gov

${ }^{3}$ Department of Chemistry, University of North Texas, NT Station, Box 305070, Denton, TX 76203-5070. Phone: 940-565-3823. Fax: 940-565-4318. E-mail: apm0010@unt.edu

EMSP Project: $\quad$ \#81935

Contract or Grant \#: $\quad$ DE-AC05-00OR22725 (FWP No. ERKP607, ORNL), DE-AC06-76RLO-1830 (PNNL), DE-FG07-98ER14936 (UNT)

Project Duration: $\quad$ Oct. 1, 2001 - Sept. 30, 2004

Program Officer: $\quad$ Gary K. Jacobs, Oak Ridge National Laboratory, Oak Ridge, TN 37831-6037, P.O. Box 2008, Bldg. 1505. Phone: (865) 574-7374. Fax: (865) 574-7287. E-mail: jacobsgk@ornl.gov .

Number of undergraduate students: 0

Number of graduate students: 6

Number of postdocs: 1 


\begin{abstract}
In this project, now completing its third year of its second renewal period, a collaborative project involving Oak Ridge National Laboratory, Pacific Northwest National Laboratory, and the University of North Texas has been addressing outstanding questions regarding the separation of the bulk sodium constituents of alkaline tank waste. The principal potential benefit of this research is a major reduction in the volume of radioactive tank waste, obviating the building of expensive new tanks and reducing the costs of vitrification. As a general approach, principles of ion recognition are being explored toward discovery and basic understanding of liquid-liquid extraction systems that selectively separate sodium hydroxide and sodium salts from waste-like matrices. Questions being addressed pertain to applicable extraction equilibria and how extraction properties relate to extractant structure. Progress has included the elucidation of the promising concept of pseudo hydroxide extraction (PHE), demonstration of crown-ether synergized PHE, demonstration of combined sodium hydroxide/sodium nitrate separation, and synthesis of novel ditopic receptors for ditopic PHE. In future efforts (pending renewal), a thermochemical study of PHE relating extractant acidity to extraction strength is proposed, and this study will be extended to systems containing crown ethers, including proton-ionizable ones. A series of crown ethers will be synthesized for this purpose and to investigate the extraction of bulk sodium salts (e.g., nitrate, nitrite, and sulfate), possibly in combination with sodium hydroxide. Simple proof-of-principle tests with real tank waste at PNNL will provide feedback toward solvent designs that have desirable properties. In view of the upcoming milestone of completion of the second renewal period, this report will, in addition to providing a summary of the past year's progress, summarize all of the work completed since the start of this project.
\end{abstract}

\title{
Research Objectives
}

General objectives. The overall goal of this research conducted under the auspices of the USDOE Environmental Management Science Program (EMSP) is to provide a scientific foundation upon which the feasibility of new liquid-liquid extraction chemistry applicable to the bulk reduction of the volume of tank waste can be evaluated. Disposal of high-level nuclear waste is horrendously expensive, in large part because the actual radioactive matter in the tanks has been diluted over 10,000-fold by ordinary inorganic chemicals. ${ }^{1}$ Quite simply, if the radioactive matter and bulk inorganic chemicals could be separated into separate streams, large cost savings would accrue, because the latter stream is much cheaper to dispose of. In principle, one could remove the radionuclides from the waste, leaving behind the bulk of the waste; or one could remove certain bulk chemicals from the waste, leaving behind a mixture of radionuclides and minor inorganic salts. The preponderance of effort over the past two decades has focused on the former approach, which produces a high-level stream for vitrification and a low-activity stream for either vitrification (Hanford) or grout (Savannah River). At Hanford, a particular concern arises in that vitrification of a large volume of low-activity waste will be unacceptably expensive. To make matters worse, a projected future deficit of tank space may necessitate construction of expensive new tanks. These problems have raised questions as to whether a solution could be devised based on separation of sodium from the waste, resulting in the reduction of the total volume of waste that must be vitrified. ${ }^{2}$

The research reported herein focuses on fundamental chemistry that could support 
development of methods for separation of sodium hydroxide and sodium salts from alkaline tank wastes. In particular, sodium hydroxide is an attractive target, because it is a bulk waste constituent that can be recycled, and it is also compatible with grout, possibly enhancing the regulatory acceptability of this economical waste form. Waste retrieval and sludge washing, for example, will require copious amounts of sodium hydroxide. If the needed sodium hydroxide could be separated from the waste and recycled, the addition of fresh sodium hydroxide could be avoided, ultimately reducing the final waste volume and associated disposal costs. ${ }^{3}$ Although the percent volume reduction is rather modest, perhaps $15 \%$, the savings is possibly still significant and may be enough to avoid construction of new tanks. Even more tantalizing, if nitrate and nitrite anions in the waste could be reduced to nitrogen gas and hydroxide (e.g., electrochemically), the bulk of the sodium in the waste could then be separated as a single component, sodium hydroxide.

Based on the above considerations, the major objective of this project since FY 1998 has been to explore new solvent-extraction approaches to the selective separation of sodium hydroxide from alkaline tank wastes. In the renewal period beginning in FY 2002, attention is also being given to the separation of salts of the other abundant anions, especially nitrate. A comprehensive approach toward understanding the extractive chemistry of sodium salts is envisioned, involving systems of varying complexity, from use of simple solvents to new bifunctional host molecules for sodium cation exchange. Ideal extractants will require no adjustment of the waste composition and will release the extracted salt into water, thereby consuming no additional chemicals and producing no additional waste volume.

This research reported herein was carried out in a collaboration involving Oak Ridge National Laboratory (ORNL), Pacific Northwest Laboratory (PNNL), and the University of North Texas (UNT). ORNL and PNNL investigated the extraction chemistry, and UNT synthesized new crown ethers.

Objectives for the past year. Experiments were carried out to understand the underlying properties of the controlling equilibria in pseudo hydroxide extraction (PHE, see below) using 1octanol as the diluent. Additional fluorinated alcohols and phenols that function by cation exchange at elevated $\mathrm{pH}$ values were tested. Synergized PHE using a crown ether was examined, especially with a view toward increasing sodium nitrate extraction efficiency and thereby boosting the total fraction of sodium that may be extracted from the waste. New ionizable lariat ethers were synthesized and tested as representatives of the class of ditopic PHE materials (UNT). The primary goal of the extraction experiments using these compounds was to demonstrate that PHE is operating and to determine whether the ditopic receptors offer advantages over the simpler synergized PHE systems.

\section{Background}

Making no presumption as to the best practical approach to separating sodium, we have found it very useful to consider a hierarchy of applicable fundamental chemical processes. These rely on principles of solvation, acid-base reactions, and host-guest chemistry. Table 1 lists eight basic approaches that one might take to effect a separation of sodium hydroxide or sodium salts. ${ }^{4,5}$ The first five approaches entail ion-pair extraction processes in which the extracted cation $\mathrm{M}^{+}$and anion $\mathrm{X}^{-}$may either be solvated or complexed. The receptor in each case is

indicated by a circle without implying any particular structure. The last three approaches entail 
Table 1. Fundamental Approaches Applicable to $\mathrm{NaOH}$ or $\mathrm{NaX}$ Separation using Host-Guest and Liquid-Liquid Extraction Principles

\begin{tabular}{|c|c|c|}
\hline Case & System & Organic-phase species \\
\hline$\# 1$ & No receptors & $\mathrm{MH}^{+}+\mathrm{X}^{-}$ \\
\hline$\# 2$ & Cation receptor & 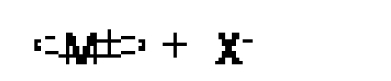 \\
\hline \#3 & Anion receptor & $M++x=X^{-}=$ \\
\hline$\# 4$ & Cation receptor + Anion receptor & :-4y=a $+8 x=$ \\
\hline$\# 5$ & Ditopic ion-pair receptor & Guty \\
\hline \#6 & Cation exchanger & $A^{-}+M^{+}$ \\
\hline$\# 7$ & Cation exchanger + Cation receptor & 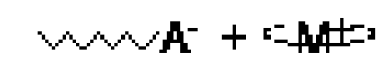 \\
\hline$\# 8$ & Proton-ionizable receptor & $\left\langle M^{+}>-A^{-}\right.$ \\
\hline
\end{tabular}

an acid-base reaction to transfer a hydroxide equivalent to the solvent with or without receptor for the cation $\mathrm{M}^{+}$. The cation exchanger is depicted with an alkyl tail to indicate lipophilicity. Although the product cation and anion species are written as free ions for all cases except \#5 and \#8, ion pairing is expected to be important in many systems to be encountered, though its effect on extraction selectivity tends to be minor relative to solvation and binding phenomena. Species may also be aggregated.

When one or both of the extracted ions is not bound by a host, as in Cases \#1, \#2, \#3, and \#6 (Table 1), then the selectivity for the unbound ion is determined solely by the solvent (in the absence of ion pairing). We have reviewed the pertinent principles of solvation, ${ }^{6,7}$ and the reader is referred to these and other sources ${ }^{8,9}$ for details. Although many fundamental interactions determine the value of $\Delta G_{\mathrm{p}}{ }^{\circ}$ for a given ion, ${ }^{9}$ statistical analysis ${ }^{10}$ indicates that the solvation of small inorganic ions is dominated by electrostatic hard-hard interactions. Thus, for $\mathrm{Na}^{+}$, the solvent must supply electron-pair donor (EPD) groups for coordination. ${ }^{6}$ Likewise for $\mathrm{OH}^{-}$and $\mathrm{NO}_{3}^{-}$hydrogen-bond donor (HBD) groups are needed. ${ }^{7}$ In principle, for favorable ion partitioning, the EPD and HBD groups must be significantly stronger than the $\mathrm{H}_{2} \mathrm{O}$ molecules in the source phase. This is difficult to achieve in a water-immiscible liquid, and indeed, ion partitioning for typical inorganic ions is unfavorable $\left(\Delta G_{\mathrm{p}}{ }^{\circ}>0\right){ }^{8}$

Solvation effects provide strong selectivity that may be best categorized as "bias" rather than "recognition". ${ }^{7}$ Specifically, the partitioning process tends to select on the basis of ion size for ions of like charge, usually favoring large or charge-diffuse $\left(q^{2} / r\right)$ ions; there is no "recognition" per se, because it is always possible to find a more highly selected ion, namely a more charge-diffuse one. Thus, for ions pertinent to present purposes, we normally obtain the selectivity orders (thermochemical radii in nm in parentheses): ${ }^{7,8} \mathrm{Cs}^{+}(0.167)>\mathrm{K}^{+}(0.138)>\mathrm{Na}^{+}$ $(0.102)$ and $\mathrm{TcO}_{4}^{-}(0.252)>\mathrm{NO}_{3}^{-}(0.196)>\mathrm{Cl}^{-}(0.172)>\mathrm{OH}^{-}(0.133)$. We have termed such solvation-based selectivity for anions as Hofmeister bias, ${ }^{11}$ in reference to the ordering of anions by hydration first noted by Franz Hofmeister. ${ }^{12}$ One mainly manipulates solvation bias by varying the EPD and HBD strength of the diluent, though one cannot thereby change the ordering of ions fundamentally. Rather, one only changes the magnitude of the bias. ${ }^{7}$ In 
principle, then, bias may be reversed for cations and anions, respectively, when the EPD and HBD strengths of the solvent exceed that of water. In this case, charge-dense ions would be selected in a competitive extraction. Unfortunately, most water-immiscible solvents fail to meet these conditions, and thus Hofmeister bias is ubiquitous.

Ironically, cation exchange provides an alternative approach for an effective separation of $\mathrm{OH}^{-}$ion. Possessing exchangeable acidic protons, cation-exchange extractants (HA) have many variants, as found in standard texts. ${ }^{13}$ Focusing on univalent ions and neglecting aggregation, cation exchange as driven by neutralization of the released hydrogen ion by hydroxide may be written most simply as:

$$
\begin{gathered}
\mathrm{Na}^{+}(\mathrm{aq})+\mathrm{OH}^{-}(\mathrm{aq})+\mathrm{HA}(\text { org }) \rightleftharpoons \mathrm{Na}^{+}(\text {org })+\mathrm{A}^{-}(\text {org })+\mathrm{H}_{2} \mathrm{O}(\mathrm{aq}) \\
\mathrm{Na}^{+}(\mathrm{aq})+\mathrm{OH}^{-}(\mathrm{aq})+\mathrm{HA}(\text { org }) \rightleftharpoons \mathrm{Na}^{+} \mathrm{A}^{-}(\text {org })+\mathrm{H}_{2} \mathrm{O}(\mathrm{aq})
\end{gathered}
$$

The reverse reaction affords recovery of sodium hydroxide upon stripping with water, whereby the alcohol returns to its protonated form in the organic phase. When used in tandem, the forward and reverse steps constitute a cyclic process affording the transfer of alkali metal hydroxide from an aqueous mixture into water. ${ }^{14}$ Because only hydroxide equivalents rather than actual hydroxide ions are transferred, this approach has been termed pseudo hydroxide extraction (PHE, Case \#6 in Table 1). ${ }^{4,15}$ Surprisingly, a single study involving phenols represents the only citation of such a process in the literature prior to our work. ${ }^{19}$

\section{Research Progress and Implications}

\section{Summary of Prior Results}

This section outlines progress in the first three years of this project, for which a detailed progress report has been issued. ${ }^{20}$ Eight fundamental approaches to hydroxide extraction were considered (Table 1). ${ }^{4}$ Two promising approaches among them were introduced and received focused attention, PHE (Case \#6) and synergized PHE (SPHE, Case \#7). PHE represents the most developed concept in terms of a possible application. A patent has been issued. ${ }^{14}$ Applied development was spun-off into a separately funded one-year project that demonstrated that recovery of $\mathrm{NaOH}$ from actual waste is possible for recycle to sludge washing. ${ }^{21}$ Although the concept appears viable, issues identified include selectivity, phase behavior, and stripping efficiency. The first observation of SPHE was communicated, ${ }^{22}$ wherein it was shown that enhanced $\mathrm{NaOH}$ extraction may be effected by combining fluorinated alcohols with macrocyclic extractants. Although the macrocycles used alone tend to favor the extraction of salts of large anions, sodium extraction from hydroxide solutions jumps sharply when the macrocycles are combined with certain lipophilic fluorinated alcohols or phenols. Large synergistic effects were demonstrated, sufficient to make hydroxide separation competitive with the more abundant nitrate. Prof. Alan Marchand and his group at UNT carried out the synthesis of novel crown ethers and podands. ${ }^{23-26}$ Synthetic methodology was devised to produce new cage-annulated oxa-, thia-, and aza-crown ethers that possess varying cavity sizes and shapes and that differ in the number and nature of the donor atoms in the macrocyclic system. Crystal structures provided valuable information on the macrocycles' preferred conformations. ${ }^{27}$ By appropriate variation of 
macrocycle structure, the strength and selectivity of extraction of alkali metal cations may be controlled, as shown in standard picrate extraction surveys. ${ }^{23,26}$

\section{Results in the Past Three Years}

Pseudo Hydroxide Extraction. Experiments were focused on questions related to the capacity and selectivity of lipophilic weak cation exchangers and to the underlying extraction mechanism. Figure 1 displays the major cation exchangers examined, including alkyl phenols and lipophilic fluorinated alcohols. Compounds $\mathbf{2 a - c}$ are new compounds.

A study was completed to address several issues pertaining to solvent capacity. ${ }^{15}$ High capacity is essential in view of the high concentration of sodium that we wish to separate. It was found that good loading of the solvent to approximately $1 \mathrm{M}$ sodium can be achieved, but high solvent viscosity or even gelation occurs at $25{ }^{\circ} \mathrm{C}$. This may be overcome by performing extraction and stripping at $60{ }^{\circ} \mathrm{C}$, and isotherms have been obtained for several candidate extractants. Extraction strength increases qualitatively with hydroxyl proton acidity, being strongest with two alkyl phenols (1a and 1b) and 4- $n$-octyl- $\alpha, \alpha$-bis(trifluoromethyl)benzyl alcohol (2a). Complete and selective removal of free hydroxide from a solution containing sodium hydroxide, nitrate, and aluminate was accomplished using $1 \mathrm{M}$ 4-tert-octylphenol (1a) at $60^{\circ} \mathrm{C}$. Aluminum precipitates slowly as $\mathrm{Al}(\mathrm{OH})_{3}$ from the hydroxide-depleted aqueous phase. At least two extractants for PHE appear to be viable for process use in terms of efficacy and cost (1a and $\mathbf{1 b}$ ), though the fluorinated alcohols may have superior stability, yet to be investigated.

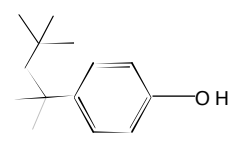

$1 \mathbf{a}$

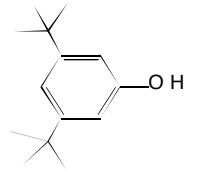

1b

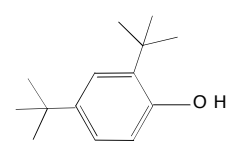

1c

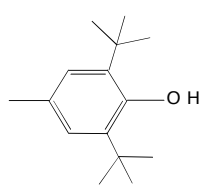

$1 d$

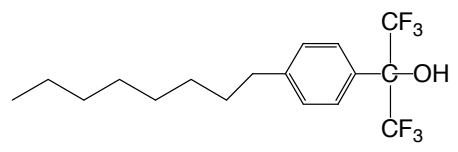

2a

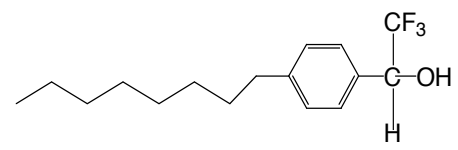

2b

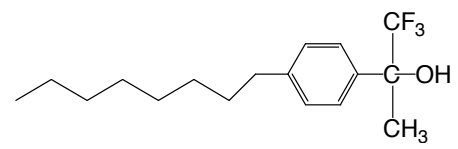

2c

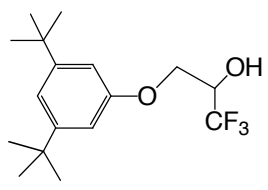

3

$\mathrm{HF}_{2} \mathrm{C}\left(\mathrm{CF}_{2}\right)_{7} \mathrm{CH}_{2} \mathrm{OH}$

4

Figure 1. Compounds investigated for pseudo hydroxide extraction. 
Considerable insight into the extraction mechanism of PHE was gained. Spectroscopic experiments were conducted to probe sodium hydroxide extraction from aqueous media by three fluorinated alcohols and a phenol in 1-octanol. ${ }^{28}$ Specifically, it was the aim to use vibrational spectroscopy to identify a signature of the putative alkoxides or phenoxide, which could clarify whether the extraction mechanism involves the postulated ion exchange as opposed to ion-pair extraction, thought to be less likely. Infrared and Raman spectra were collected from the pure extractants in 1-octanol as well as in extracts of aqueous sodium hydroxide solutions. The authentic alkoxide or phenoxide of each extractant was prepared independently, and its spectrum was obtained to assist in the assignment of the bands observed in the extracts. In all cases, the extracts contained only two discernable species, that of the starting alcohol or phenol and the corresponding alkoxide or phenoxide. This result thus confirms the cation-exchange mechanism.

In light of the spectroscopic results, investigations are under way to identify the chemical equilibria responsible for $\mathrm{PHE}$ and to measure the corresponding extraction constants. Experiments completed to date ${ }^{18,29}$ show that PHE by the weak-acid extractants (HA) in 1-octanol can indeed be quantitatively modeled by a basic cation-exchange process in which salts in the solvent formed by the deprotonated weak acids can be ion-paired or dissociated. Ion pairing predominates, however, as the dissociation into free ions becomes important only at organic-phase concentrations of sodium below $10^{-4} \mathrm{M}$. Extensive data sets have been collected for 1-octanol alone, phenol $\mathbf{1 b}$, and fluorinated alcohol $\mathbf{3}$ in 1-octanol as a function of the concentrations of organic-phase extractant and aqueous $\mathrm{NaOH} .{ }^{18}$ At an aqueous $\mathrm{NaOH}$ concentration of $1 \mathrm{M}$, the organic-phase concentration of sodium is only $7.6( \pm 0.2) \times 10^{-4} \mathrm{M}$, but addition of $\mathbf{1 b}$ or $\mathbf{3}$ strongly enhances extraction. ${ }^{18}$ The data have been subjected to rigorous mass-action analysis using the program SXLSQI. The results quantitatively confirm the postulated model given by eqs. 3-6 in Table 2.

We have extended the study to the other compounds in Fig. 1, establishing the generality of our model to these other cation exchangers. Table 2 defines the equilibria in the model. Equations 5 and 6 are defined by subtraction of the water autoionization from respectively eqs. 1 and 2 to express the reactions in terms of hydrogen ion dissociation, the usual way to describe an acid dissociation process. Table 3 reports the $\log K$ values found for the various compounds studied. The $\log K$ entries for 1-octanol account for the weak extraction without an added HA. These background $\log K$ values remain constant for all HA compounds. One may note from the values of $\log K_{5}$ and $\log K_{6}$ that the organic acids are indeed very weak and will be appreciably

Table 2. Equilibria Associated with Sodium Extraction

\begin{tabular}{|c|c|c|c|}
\hline Eq. No. & & & Equation \\
\hline 3 & $\mathrm{Na}^{+}(\mathrm{aq})+\mathrm{OH}^{-}(\mathrm{aq})$ & $\stackrel{K_{3}}{\longrightarrow}$ & $\mathrm{Na}^{+}($org $)+\mathrm{OH}^{-}($org $)$ \\
\hline 4 & $\mathrm{Na}^{+}(\mathrm{aq})+\mathrm{OH}^{-}(\mathrm{aq})$ & $\stackrel{K_{4}}{\longrightarrow}$ & $\mathrm{Na}^{+} \mathrm{OH}^{-}$(org) \\
\hline 5 & $\mathrm{Na}^{+}(\mathrm{aq})+\mathrm{HA}($ org $)$ & $K_{5}$ & $=\mathrm{Na}^{+}($org $)+\mathrm{A}^{-}($org $)+\mathrm{H}^{+}(\mathrm{aq})$ \\
\hline 6 & $\mathrm{Na}^{+}(\mathrm{aq})+\mathrm{HA}($ org $)$ & $K_{6}$ & $=\mathrm{Na}^{+} \mathrm{A}^{-}($org $)+\mathrm{H}^{+}(\mathrm{aq})$ \\
\hline
\end{tabular}


Table 3. Equilibrium Constants Obtained from SXLSQI

\begin{tabular}{ccccc}
\hline & $\log K_{3}$ & $\log K_{4}$ & $\log K_{5}$ & $\log K_{6}$ \\
\hline \multirow{2}{*}{ 1-Octanol } & -7.86 & -2.74 & & \\
& \pm 0.07 & \pm 0.03 & & \\
\multirow{1}{*}{$\mathbf{a}$} & & & -18.47 & -13.14 \\
& & & \pm 0.11 & \pm 0.01 \\
$\mathbf{1 b}$ & & & -18.89 & -13.50 \\
& & & \pm 0.11 & \pm 0.01 \\
$\mathbf{1 c}$ & & & -20.23 & -15.60 \\
& & & \pm 0.12 & \pm 0.06 \\
$\mathbf{2 a}$ & & & -19.83 & -12.25 \\
& & & \pm 0.07 & \pm 0.02 \\
$\mathbf{2 b}$ & & & -19.83 & -15.01 \\
& & & -20.00 & -15.62 \\
$\mathbf{2 c}$ & & & \pm 0.10 & \pm 0.04 \\
& & & -19.58 & -14.62 \\
$\mathbf{3}$ & & & \pm 0.10 & \pm 0.01 \\
& & & -19.03 & -14.74 \\
$\mathbf{4}$ & & & \pm 0.09 & \pm 0.02 \\
\hline
\end{tabular}

deprotonated only at $\mathrm{pH}$ values greater than 12. At practical loadings, eq. 6 dominates, and one may thus compare extraction strengths based on $\log K_{6}$. Extraction efficiency follows the qualitative order of acidity of the HAs, $\mathbf{1 a}>\mathbf{1 b}>\mathbf{1 c}>\mathbf{1 d}$ and $\mathbf{2 a}>\mathbf{2 b}>\mathbf{2 c}$, reflecting a combination of inductive effects as well as steric constraints to solvation of the deprotonated anionic product species.

Synergized pseudo hydroxide extraction. In recently published work, ${ }^{5}$ SPHE was examined using a series of lipophilic weak-acid extractants (HA) including fluorinated alcohols and phenols in combination with $\csc$-DC18C6 in nitrobenzene (NB). The high permittivity of NB favors dissociation of ion-pairs, making it easier to discern separate binding and protondissociation processes. The nature of the proton-ionizable extractant was found to have a strong effect, both on extraction strength and selectivity. Sodium extraction by the crown ether used alone was quantified, and the corresponding equilibrium constants $\left(\log K_{\text {ext }}\right)$ correlated with the standard Gibbs energy $\left(\Delta G_{\mathrm{p}}{ }^{\circ}\right)$ of anion partitioning into NB; extraction was weak and nonselective for the hydroxide ion, in accord with Hofmeister bias. Upon addition of HA into the crown ether solution in NB, sodium extraction was selectively enhanced for hydroxide. The resulting SPHE qualitatively correlates with the aqueous $\mathrm{p} K_{\mathrm{a}}$ of the employed HA; the most acidic cation exchangers provide the greatest synergism. The synergistic factor obtained using a fluorinated alcohol was as high as 256. One particularly effective synergistic combination of crown with 2a preferentially extracted $\mathrm{NaOH}$ over all other sodium salts, including the strongly extracted nitrate and perchlorate salts. Quantitative recovery of $\mathrm{NaOH}$ from the NB phase was demonstrated upon a single contact of the loaded solvent with water. 
Combined Sodium Hydroxide and Sodium Nitrate Extraction. The feasibility of extracting both sodium hydroxide and sodium nitrate, two major sodium components of the tank waste, has been under investigation in the past year at PNNL. ${ }^{30}$ Building on the concept of PHE, the approach taken was to introduce a neutral receptor capable of binding sodium ion, essentially in the manner of SPHE. The combination of a weak lipophilic cation exchanger (e.g., alkylated phenol) and a neutral sodium receptor (e.g., crown ether) in a suitable organic diluent thus will allow separation of the sodium ion via two mechanisms: hydroxide-driven ion-exchange and ionpair extraction. The question being addressed concerns whether one can extend this concept to a simultaneous removal of $\mathrm{NaOH}$ and $\mathrm{NaNO}_{3}$ by a single $\mathrm{SPHE}$ solvent system.

Given that the alkalinity and corresponding $\mathrm{OH}^{-} / \mathrm{NO}_{3}{ }^{-}$concentration ratio of the waste varies from tank to tank, SPHE as opposed to simple PHE provides a universal approach to effective $\mathrm{Na}^{+}$extraction independently of its chemical form present in the waste solution. It also makes possible successful design of a multicycle extraction separation process. It may be envisioned that on multiple contacts of the aqueous waste by small volumes of fresh solvent, the hydroxide ion in the aqueous phase will be gradually depleted by PHE, which then gives way to ion-pair extraction of sodium nitrate. Overall, more sodium may be extracted, as it is not limited by the hydroxide content of the waste solution. To this end, the high concentration of nitrate ion in the aqueous waste is desirable, as its moderately large radius relative to other univalent aqueous inorganic anions makes it the most extractable bulk anion in the waste stream. It may also be expected that water stripping will be possible. It was discussed above that ion-pair extraction by use of a crown ether is reversible upon contact of the solvent with water. By analogy with PHE, SPHE is also reversible by water stripping, provided HA is very weak.

One of the challenges of making this type of system practical, however, results from the desirability of employing an aliphatic hydrocarbon diluent. The enhanced SPHE extraction strength toward $\mathrm{NaOH}$ is expected to allow flexibility in diluent selection, for example, substitution of 1-octanol with an aliphatic diluent like Isopar ${ }^{\circledR} \mathrm{L}$, a branched isoparaffinic diluent. Added crown ether is also expected to improve phase behavior in that its binding of the metal ion effectively deaggregates lipophilic metal salts at high loading. ${ }^{31}$

A crown ether representing the 18-crown-6 family, namely 4,4'(5')-di-tert-butylcyclohexano18-crown-6 and two cation exchangers of different acidity, 1,1,1-trifluoro-3-(3,5-di-tertbutylphenoxy)-2-propanol $\mathbf{3}\left(\mathrm{p} K_{\mathrm{a}}=12.5^{5}\right)$ and 3,5-di-tert-butylphenol $\mathbf{1 b}\left(\mathrm{p} K_{\mathrm{a}}=9.9^{5}\right)($ Fig. 2), were tested using Isopar ${ }^{\circledR} \mathrm{L}$ diluent and three kinds of aqueous phases: $\mathrm{NaOH}, \mathrm{NaNO}_{3}$, and their combination. These experiments revealed strong SPHE at high alkalinity and moderate ion-pair extraction of sodium nitrate under neutral conditions. Effect of the HA acidity on SPHE and ionpair extraction was pronounced, phenol $\mathbf{1 b}$ being stronger than fluorinated alcohol $\mathbf{3}$. As expected, reverse efficiency order was observed for stripping. Combined extraction of sodium hydroxide and nitrate was demonstrated. The contribution of the $\mathrm{NaNO}_{3}$ ion-pair extraction to the overall $\mathrm{Na}^{+}$extraction was found to be dependent upon HA acidity and concentration in the diluent and was significantly higher for the less acidic 3. It was shown to be possible to strip the extracted sodium with water. Although the results are promising, the following needs were identified: a) increased solubility of neutral and proton-ionizable extractants, b) higher sodium loading, and c) higher sodium nitrate extraction efficiency. 


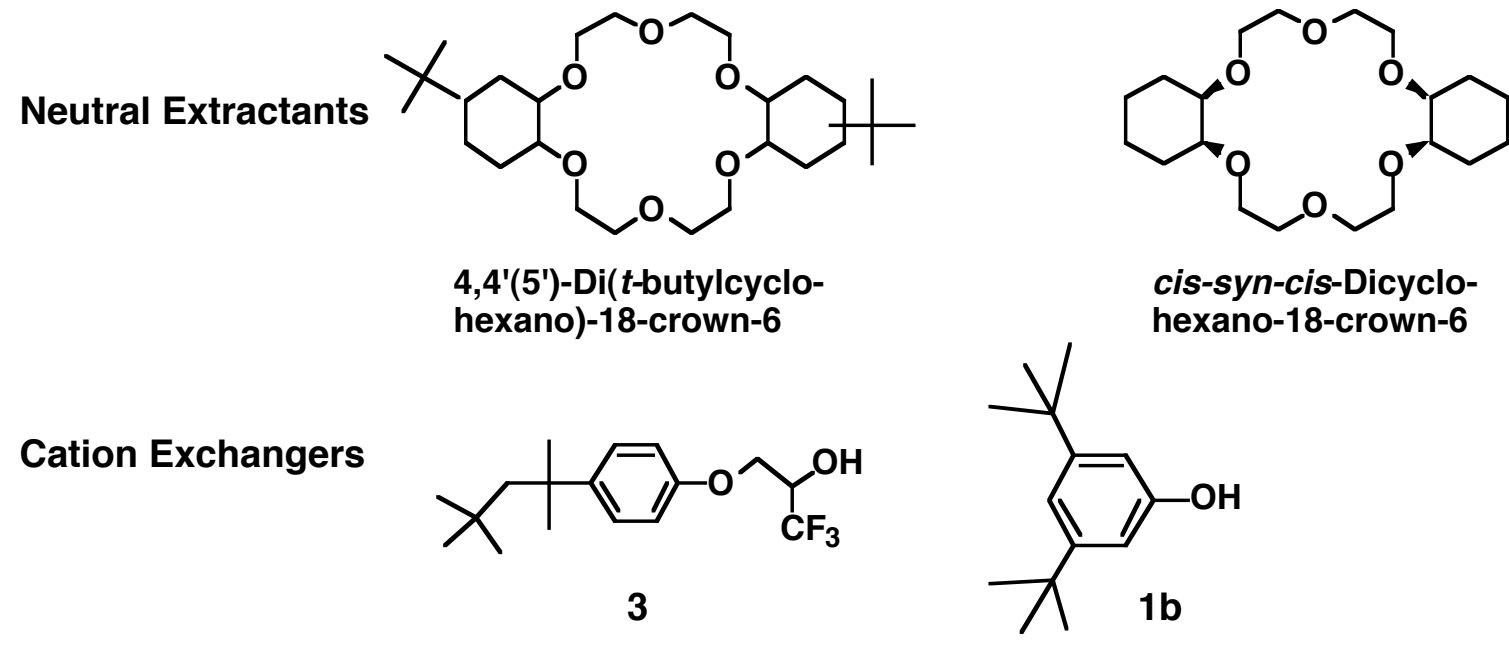

\section{Solvent Modifiers}

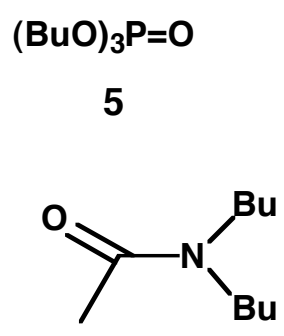

9

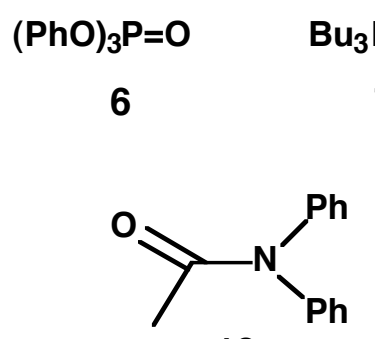

10
$\mathrm{Ph}_{3} \mathrm{P}=\mathrm{O}$

8

7

$\mathrm{CH}_{3}\left(\mathrm{CH}_{2}\right)_{7} \mathrm{OH}$

11

Figure 2. Crown Ethers, Cation Exchangers, and EPD Modifiers Employed.

Effect of EPD modifiers on $\mathrm{NaNO}_{3}$ ion-pair extraction. Under neutral conditions, our results with crown ethers demonstrated that certain lipophilic alcohols mildly enhance $\mathrm{NaX}$ extraction by anion solvation. ${ }^{5}$ Further enhancement of sodium nitrate extraction is desirable, and we proposed the use of modifiers with electron-pair donor (EPD) groups to lower the sodium ion partitioning energy. The detailed investigation of such modifiers was conducted at PNNL. Again, csc-DC18C6 (Fig. 5) served as a model lipophilic sodium extractant. As documented by numerous crystal structures, encapsulation of $\mathrm{Na}^{+}$into the crown ether cavity often does not saturate its inner coordination sphere, and as a result, $\mathrm{Na}^{+}$readily coordinates additional ligands such as water or organic solvent molecules, oxygen donor anions, or another crown ether molecule to form a sandwich complex. ${ }^{32}$ To this end, it seems feasible to exploit this effect by introducing EPD solvating agents into the solvent. A series of EPD modifiers with strong Hbond acceptor abilities was investigated, including tri- $n$-butyl- and triphenylphosphate, tri- $n$ butyl- and triphenylphosphine oxide, $N, N$-di- $n$-butyl- and $N, N$-di-phenylacetamide, and 1-octanol (Fig. 2). The extraction behavior of $c s c$-DC18C6 was characterized by systematic variation of the aqueous-phase sodium nitrate concentration at fixed composition of the NB phases containing 0.2 M EPD modifier and 0.05 M csc-DC18C6 (Fig. 3). Comparison of the extraction isotherms obtained with and without EPD modifiers in the NB phase indicates that the EPD modifiers moderately increase $\mathrm{NaNO}_{3}$ extraction by $\csc$-DC18C6. Distribution results for the crown ether used alone or with the solvating agents were successfully fit using the SXLSQI modeling program, whereupon the obtained extraction constants were found to correlate linearly 
with the EPD strength of the added modifiers described by the Kamlet-Taft $\beta$ solvatochromic parameter $^{33}$ (Figure 4-a). These results provide the means for the quantitative prediction of the extraction performance of the modified diluent. In the presence of the phenol, the EPD solvating agents slightly lowered $\mathrm{NaNO}_{3}$ extraction by $\csc$-DC18C6 and phenol, which, however, remained higher than $\mathrm{NaNO}_{3}$ extraction by $c s c$-DC18C6 alone. This slight reduction in extraction strength was attributed to the competitive interaction between phenol and EPD modifier.

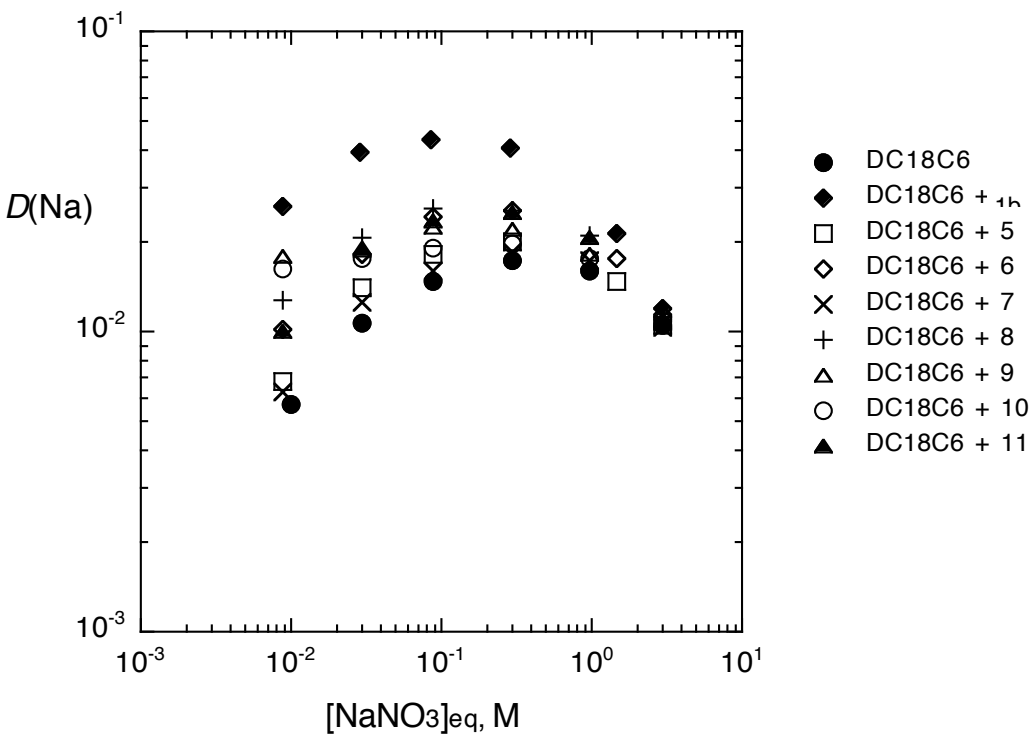

Figure 3. Dependence of $\mathrm{NaNO}_{3}$ extraction on the aqueous $\mathrm{NaNO}_{3}$ concentration by cscDC18C6 into NB with and without solvent modifier.
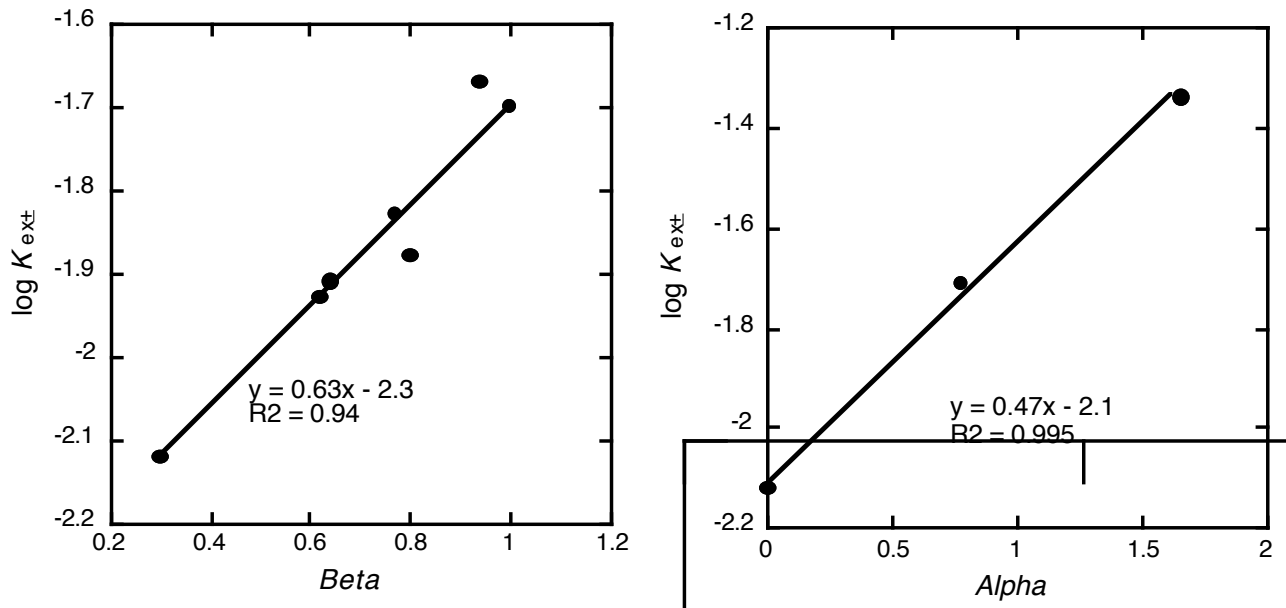

Figure 4. Dependence of $\mathrm{NaNO}_{3}$ extraction by $c s c-\mathrm{DC} 18 \mathrm{C} 6$ into NB on a) basicity of the EPD solvent modifier or b) hydrogen-bond donicity of the HBD solvent modifier. 
Investigation of hydrogen bonding in ion-pair extraction. Addition of a weak organic acid to an organic phase lowers the anion-partitioning energy barrier based upon an H-bond interaction between the organic acid and the anion. ${ }^{9,10}$ As demonstrated previously, the stability of the anionic solvate formed in the NB phase depends on the $\mathrm{p} K_{\mathrm{a}}$ of the organic acid. ${ }^{5}$ Quantitative assessment of this effect on the $\mathrm{NaNO}_{3}$ extraction was conducted employing solvating agents $\mathbf{1 b}$ and $\mathbf{1 1}$ possessing different abilities to donate an $\mathrm{H}$-bond as given by the solvatochromic parameter ${ }^{33} \alpha$ equal to 0.77 and 1.65, respectively. 1-Octanol 11 also exhibits EPD properties similar to those of EPD modifiers discussed above; its $\beta$ parameter ${ }^{33}$ is 0.81 . Phenol $\mathbf{1 b}$ is a weak EPD with a $\beta$ parameter of 0.3 , similar to that of $\mathrm{NB}^{33}$ The extraction behavior of $\csc$-DC18C6 was characterized by systematic variation of the aqueous-phase sodium nitrate concentration at fixed composition of the NB phases containing $0.2 \mathrm{M} \mathbf{1 b}$ or $\mathbf{1 1}$ and 0.05 M csc-DC18C6 (Fig. 3). 1-Octanol 11 exhibited only marginal enhancement of $\mathrm{NaNO}_{3}$ extraction, on a par with the EPD modifiers tested. Significant extraction enhancement was observed with the phenol $\mathbf{1 b}$ which surpassed the performance of the EPD solvating agents. The distribution data were fit using the SXLSQI modeling program. Values of $\log K_{\mathrm{ex} \pm}$ exhibited a linear dependence on $\alpha$ (Fig. 4-b).

Understanding the effect of an HBD modifier on ion-pair extraction involves assessment of many different processes such as H-bonding with the anion, aggregation, and solvation of the free extractant and its cationic complex. While EPD properties of the solvent modifier are important in solvation of the complex cation, solvation of the free crown ether is based upon specific H-bond interactions with the HBD groups of the modifier. One example is the hydration of crown ethers, a phenomenon which was extensively investigated over the last two decades. ${ }^{33}$ Among organic acids, formation of the phenol-crown ether H-bond-based aggregates in the solid state was found to influence the conformation of the macrocycle. ${ }^{34}$ In solution, a similar effect was demonstrated in a study of the reverse-phase HPLC separation of phenol and its derivatives. ${ }^{35}$ For compounds containing the hydroxyl group, the addition of 18 -crown- 6 to the mobile phase led to a decrease in retention time, which was explained by the complexation between the hydroxy compounds and the crown ether. This H-bonding of the HBD modifier to the oxygen donor atoms of the crown ether could potentially compete with metal ion interaction and partially suppress the gain in extraction due to favorable anion solvation by HBD modifier.

To probe $\mathrm{H}$-bonding interactions in the NB extraction phase, an IR investigation of the $\mathrm{O}-\mathrm{H}$ bonds of phenol and water in NB in the presence of free or $\mathrm{Na}^{+}$-loaded crown ether $\csc$ DC18C6 is under way. A series of FTIR spectra of the water-washed solutions of phenol $\mathbf{1 b}$ in the $0.05-0.8 \mathrm{M}$ concentration range were acquired. Phenol $\mathbf{1 b}$ exhibited no self-aggregation in $\mathrm{NB}$, as no signal broadening, position shift, or appearance of new bands was found for the narrow band of its $\mathrm{O}-\mathrm{H}$ group. In agreement with literature reports, ${ }^{36}$ the free crown ether $\csc$ DC18C6 in NB without phenol was found to exist in the hydrated form. The broad water O-H band in the 3200-3700 $\mathrm{cm}^{-1}$ region has three maxima corresponding presumably to a crownwater adduct in which the water molecule is coordinated to the crown ether in mono- and bidentate fashion (Fig. 5). Loading of the crown ether with $\mathrm{Na}^{+}$ion slightly shifts, and increases the relative intensity of, the high-energy water $\mathrm{O}-\mathrm{H}$ band at $3665 \mathrm{~cm}^{-1}$. Addition of the phenol to the $\mathrm{Na}^{+}$-loaded crown ether causes the appearance of the new band at $3250 \mathrm{~cm}^{-1}$ due to the $\mathrm{H}$ bonding of the phenolic $\mathrm{O}-\mathrm{H}$ group to the $\mathrm{NO}_{3}{ }^{-}$anion. This phenol-nitrate interaction lowers the energy barrier of the nitrate partitioning into NB and boosts the ion-pair sodium extraction. 


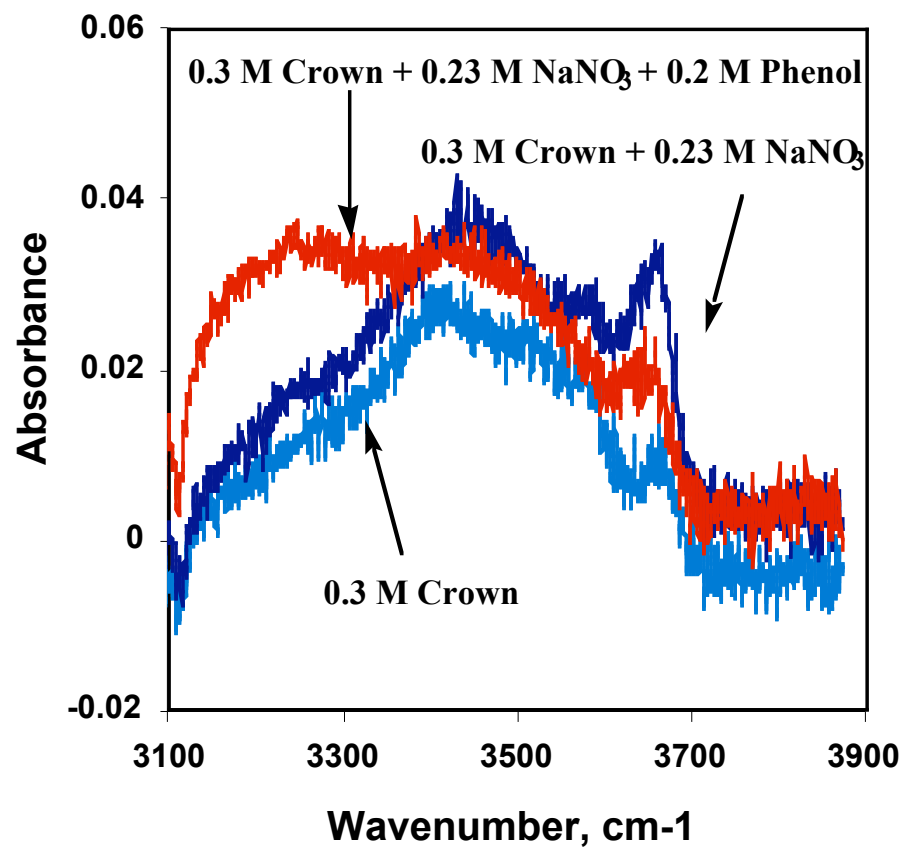

Figure 5. IR spectra of the $\mathrm{O}-\mathrm{H}$ bond of phenol and water in $\mathrm{NB}$ in presence of $\csc$-DC18C6 and/or $\mathrm{NaNO}_{3}$.

Ditopic pseudo hydroxide extraction. Synthesis efforts at UNT (A. P. Marchand) have focused on the synthesis of crown ethers ${ }^{37}$ and calixarene crown ethers ${ }^{38}$ with appended weakly ionizable functionalities. Most examples have employed cage substituents on the polyether ring to confer lipophilicity and ring rigidity. The proton-ionizable substituents are essentially the same groups used in the weakly acidic fluorinated alcohols tested for PHE. The ditopic compounds by contrast are expected to lead to a greater degree of control over cation selectivity and possibly enhanced extraction strength. The compounds shown in Figs 6 and 7 were prepared.

Survey extraction experiments under way entail examining sodium distribution ratios $\left(D_{\mathrm{Na}}\right)$ for the synthesized weakly acidic crown compounds dissolved in purified NB. The non-ionizable control compounds are run by themselves and also with added control fluorinated alcohols that match the type of ionizable group on the corresponding ditopic extractants. One ionizable control is $1 \mathrm{H}, 1 \mathrm{H}, 9 \mathrm{H}$-hexadecafluoro-1-nonanol (4), and the other is 4- $n$-octyl- $\alpha, \alpha-$ (trifluoromethyl)benzyl alcohol (2a). The former is commercially available, and the latter was prepared at ORNL by the Friedel-Crafts reaction between phenyloctane and hexafluoroacetone. ${ }^{15}$ Two experiments are being run: a) variation of aqueous $[\mathrm{NaCl}]$ and b) variation of aqueous $[\mathrm{NaOH}]$ in a constant aqueous concentration of $\mathrm{NaCl}$. The first experiment essentially measures the relative strength of $\mathrm{Na}^{+}$binding and extraction without dissociation of the terminal $-\mathrm{OH}$ group. The second experiment then measures the total $\mathrm{Na}^{+}$binding and extraction as protondissociation is "turned on". Preliminary assessment of the data collected thus far reveals expected behavior in terms of the $\mathrm{NaCl}$ and $\mathrm{NaOH}$ dependences described earlier. Unfortunately, there is as yet no evidence for any of the new ditopic compounds exhibiting enhanced $\mathrm{NaOH}$ extraction 

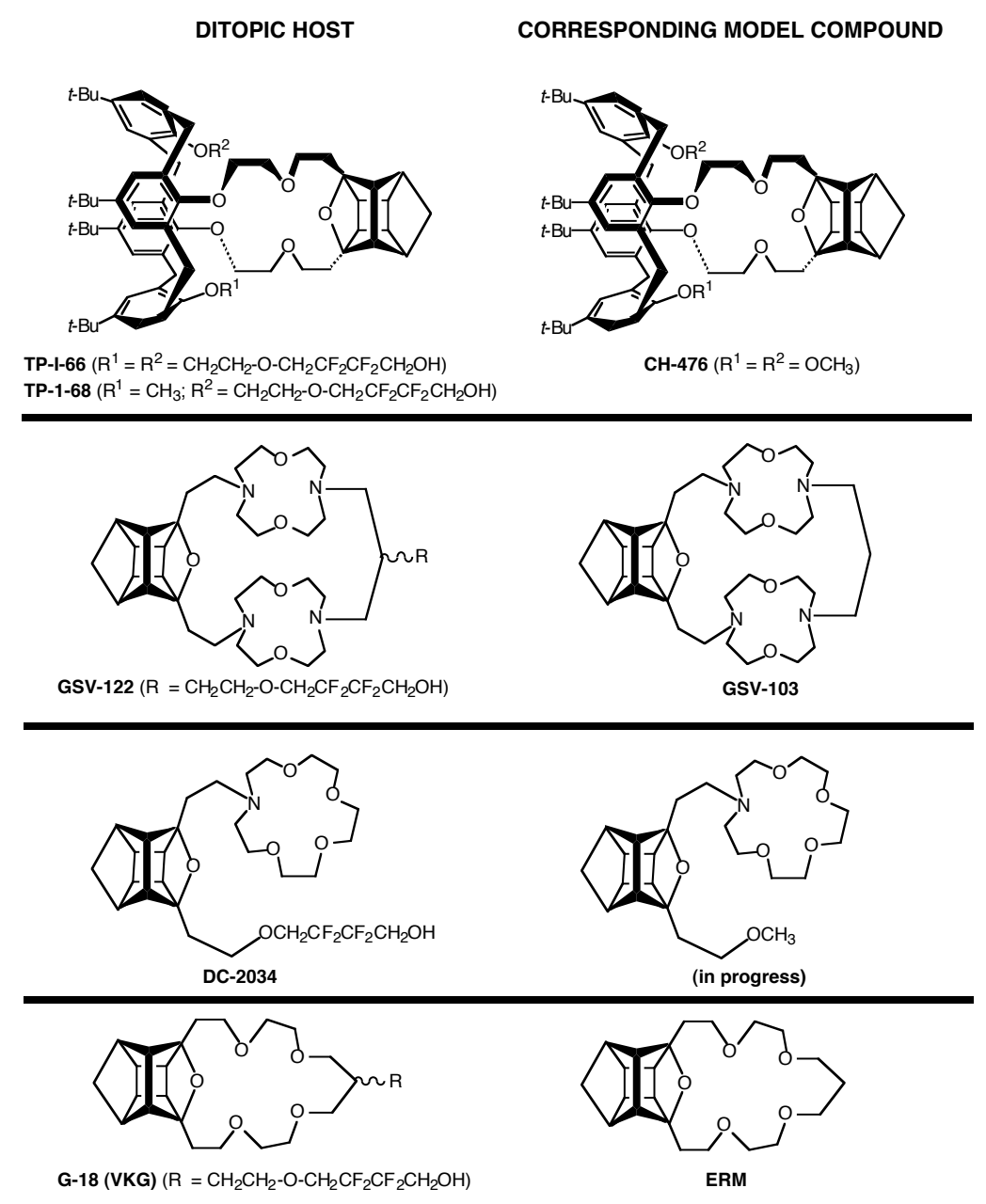

Figure 6. Synthesized weakly acidic proton-ionizable crown ethers and calixarene crown ethers for ditopic pseudo hydroxide extraction.

over and above their corresponding control systems (SPHE systems consisting of crown control plus proton-ionizable control). This may be attributed to the length of the proton-ionizable sidearms and its lack of preorganization for cooperativity with the crown ring.

\section{Planned Activities}

A renewal proposal has been submitted, outlining a plan for continued effort toward the objectives given above. In the proposed efforts, a thermochemical study of PHE relating extractant acidity to extraction strength will be completed, and this study will be extended to systems containing crown ethers, including proton-ionizable ones. A series of crown ethers will be synthesized at ORNL for this purpose as well as to investigate the extraction of bulk sodium salts (e.g., nitrate, nitrite, and sulfate), possibly in combination with sodium hydroxide. Simple proof-of-principle tests with real tank waste at PNNL will provide feedback toward solvent designs that have desirable properties. 


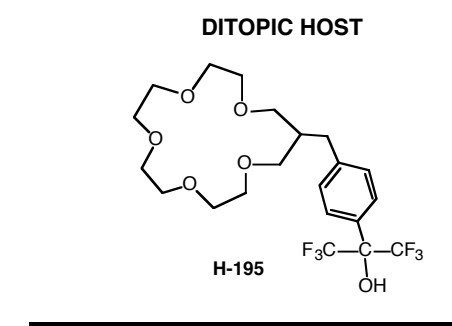

CORRESPONDING MODEL COMPOUND
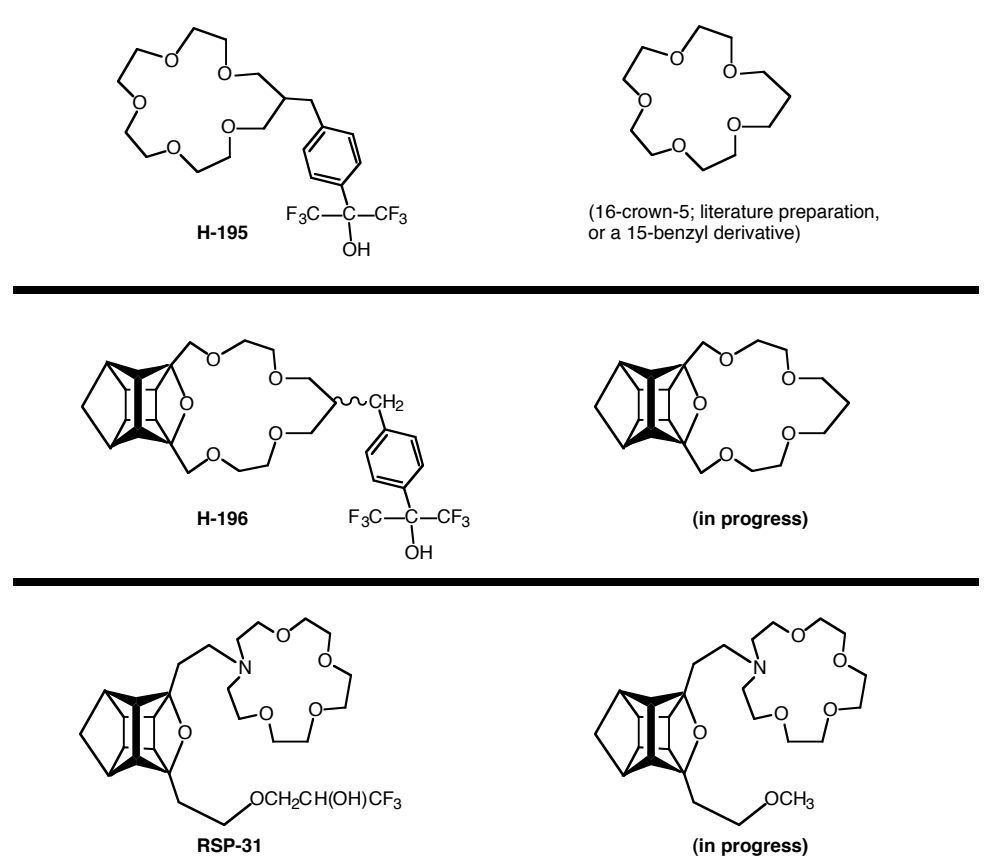

Figure 7. Additional synthesized weakly acidic proton-ionizable crown ethers and calixarene crown ethers for ditopic pseudo hydroxide extraction.

\section{Acknowledgments}

This research was sponsored by the Environmental Management Science Program of the Office of Science, U. S. Department of Energy, under a) Contract Number DE-AC0500OR22725 with Oak Ridge National Laboratory, managed and operated by UT-Battelle, LLC; b) Contract Number DE-AC06-76RLO-1830 with Pacific Northwest National Laboratory, managed and operated by Battelle Memorial Institute; and c) Grant Number DE-FG0798ER14936 with the University of North Texas. Any opinions, findings, conclusions, or recommendations expressed herein are those of the authors and do not necessarily reflect the views of DOE. Support for H.-A.K. under the Postdoctoral Fellowship Program of Korea Science \& Engineering Foundation (KOSEF) is gratefully acknowledged; the participation of H.A.K. was made possible by an appointment to the Oak Ridge National Laboratory Postgraduate Program administered by the Oak Ridge Associated Universities.

\section{References}

1. (a) TWINS Database, http://twins.pnl.gov:8001/twins.htm. (b) "Final Environmental Impact Statement: Disposal of Hanford Defense High-Level, Transuranic and Tank Wastes", Report DOE/EIS-0113 (Vol. 2 of 5) Appendix A, U.S. Department of Energy, Dec., 1987. (c) Walker, D. D.; Barnes, M. J.; Crawford, C. L.; Peterson, R. A.; Swingle, R. F.; Fink, S. D. In Science and Technology for Disposal of Radioactive Tank Wastes; Lombardo, N.; Schulz, 
W. W., Eds.; Plenum: New York, 1998, pp 219-230. (d) Bunker, B.; Virden, J.; Kuhn, B.; Quinn, R. In Encylcopedia of Energy Technology and the Environment; John Wiley \& Sons, Inc., 1995, p 2023-2032.

2. (a) Distributed flipchart information from Mission Acceleration Initiative Technology Demonstration Workshop, at Pacific Northwest National Laboratory, Richland, WA, Apr. 2-3, 2002. (b) NRC. 2000. Long-Term Research Needs for High-Level Waste at Department of Energy Sites: Interim Report. http://www.nap.edu/catalog/9992.html . (c) Program Announcement To DOE National Laboratories, LAB 01-16, Environmental Management Science Program: Basic Science Research Related to High Level Radioactive Waste; URL: http://emsp.em.doe.gov/announcements.htm (accessed Mar. 2001).

3. (a) Kurath, D. E.; Brooks, K. P.; Hollenberg, G. W.; Sutija, D. P.; Landro, T.; Balagopal, S. Sep. Purif. Technol. 1997, 11, 185-198. (b) Kurath, D. E.; Brooks, K. P.; Jue, J.; Smith, J.; Virkar, A. V.; Balagopal, S.; Sutija, D. P. Sep. Sci. Technol. 1997, 32, 1-4.

4. Moyer, B. A.; Bonnesen, P. V.; Chambliss, C. K.; Haverlock, T. J.; Marchand, A. P.; Chong, H.-S.; McKim, A. S.; Krishnudu, K.; Ravikumar, K. S.; Kumar, V. S.; Takhi, M. In Nuclear Site Remediation: First Accomplishments of the Environmental Science Program; Eller, P. G. and Heineman, W. R., Eds.; ACS Symposium Series, Vol. 778; American Chemical Society: Washington, DC, 2001; pp 114-132.

5. Levitskaia, T. G.; Bonnesen, P. V.; Chambliss, C. K.; Moyer, B. A. Synergistic PseudoHydroxide Extraction: Synergism and Anion Selectivity in Sodium Extraction Using a Crown Ether and a Series of Weak Lipophlilic Acids. Anal. Chem. 2003, 75(3), 405-412.

6. Moyer, B. A.; Sun, Y. Principles of Solvent Extraction of Alkali Metal Ions: Understanding Factors Leading to Cesium Selectivity in Extraction by Solvation. In Ion Exchange and Solvent Extraction; Marcus, Y., Marinsky, J. A., Eds.; Marcel Dekker: New York, 1997; Chap. 6, pp 295-391.

7. Moyer, B. A.; Bonnesen, P. V. Physical Factors in Anion Separations, In The Supramolecular Chemistry of Anions; Bianchi, A., Bowman-James, K., Garcia-Espana., E., Eds.; VCH: Weinheim, 1997.

8. Marcus, Y. Ion Properties; Marcel Dekker: New York, 1997.

9. Marcus, Y. Ion Solvation; Wiley: Chichester, 1985.

10. Marcus, Y.; Kamlet, M. J.; Taft, R. W. Linear Solvation Energy Relationships. Standard Molar Gibbs Free Energies and Enthalpies of Transfer of Ions from Water into Nonaqueous Solvents. J. Phys. Chem. 1988, 92, 3613-3622.

11. Kavallieratos, K.; Moyer, B. A. Attenuation of Hofmeister Bias in Ion-Pair Extraction by a Disulfonamide Anion Host Used in Strikingly Effective Synergstic Combination with a Calix-Crown $\mathrm{Cs}^{+}$Ion Host. Chem. Commun. 2001, 1620-1621.

12. Hofmeister, F. On Regularities in the albumin precipitation reactions with salts and their relationship to physiological behavior. Archiv. Exptl. Pathol. Pharmakol. 1888, 24, 247-260.

13. (a) Marcus, Y.; Kertes, A. S. Ion Exchange and Solvent Extraction of Metal Complexes; Wiley Interscience: New York, 1969. (b) Sekine, T.; Hasegawa, Y. Solvent Extraction Chemistry: Fundamentals and Applications; Marcel Dekker: New York, 1977. (c) Rydberg, J.; Musikas, C.; Choppin, G. R. Principles and Practices of Solvent Extraction; Marcel Dekker: New York, 1992.

14. Moyer, B. A.; Chambliss, C. K.; Bonnesen, P. V.; Keever, T. J. Solvent and Process for Recovery of Hydroxide from Aqueous Mixtures, U. S. Patent 6,322,702, Nov. 27, 2001.

15. Haverlock, T. J.; Bonnesen, P. V.; Moyer, B. A. Separation of NaOH by Solvent Extraction 
Using Weak Hydroxy Acids. Solvent Extr. Ion Exch. 2003, 21(4), 483-504.

16. Haverlock, T. J.; Bonnesen, P. V.; Brown, G. M.; Chambliss, C. K.; Levitskaia, T. G.; Moyer, B. A. Separation of $\mathrm{NaOH}$ from Salts by Weak Hydroxy Acids. Proc. Internat. Solvent Extraction Conf. (ISEC 2002), Cape Town, S. Africa, Mar. 17-21, 2002, Vol. 1, Sole, K. C., Cole, P. M., Preston, J. S., Robinson, J. S., Eds., Chris van Rensburg Publications, Melville, South Africa, 2002; pp 396-401.

17. Chambliss, C. K.; Haverlock, T. J.; Bonnesen, P. V.; Engle, N. L.; Moyer, B. A. Selective Separation of Hydroxide from Alkaline Media by Liquid-Liquid Extraction with Weak Hydroxy Acids. Environ. Sci. Technol. 2002, 36, 1861-1867.

18. Kang, H-A; Engle, N. L.; Bonnesen, P. V.; Delmau, L. H.; Haverlock, T. J.; Moyer, B.A. An Equilibrium Model of Pseudo-Hydroxide Extraction in the Separation of Sodium Hydroxide from Aqueous Solutions Using Lipophilic Fluorinated Alcohols and Phenols. Sep. Sci. Technol., in press.

19. (a) Grinstead, R. R. U.S. Patent 3,598,547, Aug. 10, 1971. (b) Grinstead, R. R. U.S. Patent 3,598,548, Aug. 10, 1971.

20. Moyer, B. A.; Marchand, A. P.; Bonnesen, P. V.; Bryan, J. C.; Haverlock, T. J. "Ion Recognition Approach to Volume Reduction of Alkaline Tank Waste by Separation and Recycle of Sodium Hydroxide and Sodium Nitrate," Environmental Management Science Program Fiscal Year 1998 Awards Final Report, May 31, 2002; available on the World Wide Web site of the USDOE Office of Environmental Management at URL http://emsp.em.doe.gov/.

21. Lumetta, G. J.; Garza, P. A.; Levitskaia, T. G.; Brown. G. M. 2002. Sodium Hydroxide Extraction From Caustic Leaching Solutions, PNNL-14026, Pacific Northwest National Laboratory, Richland, Washington

22. Levitskaia, T. G.; Moyer, B. A.; Bonnesen, P. V.; Marchand, A. P.; Krishnudu, K.; Chen, Z.: Huang, Z.; Kruger, H. G.; McKim, A. S. Novel Approach to Sodium Hydroxide Separation: Synergistic Pseudo Hydroxide Extraction by a Fluorinated Alcohol and CageFunctionalized Crown Ethers, J. Am. Chem. Soc. 2001, 123, 12099-12100.

23. For a review, see: Marchand, A. P.; Kumar, K. A.; McKim, A. S.; Alihodzic, S.; Chong, H.S.; Krishnudu, K.; Takhi, M. Kem. Ind. 2001, 50, 129-138.

24. (a) Marchand, A. P.; Kumar, K. A.; McKim, A. S.; Mlinaric-Majerski, K.; Kragol, G. Tetrahedron 1997, 53, 3467. (b) Marchand, A. P.; McKim, A.; Kumar, K. A. Tetrahedron, 1998, 54, 13421. (c) Marchand, A. P.; Chong, H.-S. Tetrahedron 1999, 55, 9697.

25. (a) Marchand, A. P.; Alihodzic, S.; McKim, A. S.; Kumar, K. A.; Mlinaric-Majerski, K.; Sumanovac, T.; Bott, S. G. Tetrahedron Lett. 1998, 39, 1861. (b) Marchand, A. P.; Chong, H.-S.; Alihodzic, S.; Watson, W. H.; Bodige, S. G. Tetrahedron 1999, 55, 9687. (c) Marchand, A. P.; Chong, H.-S.; Takhi, M.; Watson, W. H.; Bodige, S. G. Heterocycles 2000, 54, 151.

26. Marchand, A. P.; Huang, Z.; Chen, Z.; Hariprakasha, H. K.; Namboothiri, I. N. N.; Brodbelt, J. S.; Reyzer, M. L. J. Heterocyclic Chem. 2001, 38(6), 1361-1368.

27. (a) Bryan, J. C.; Mlinaric-Majerski, K.; Kragol, G.; Marchand, A. P., Z. Kristallogr. 2001, 216, 277-279. (b) Bryan, J. C.; Marchand, A. P.; Hazlewood, A., Acta Crystallogr. E 2001, 57, o13-15. (c) Bryan, J. C.; Levitskaia, T. G.; Giacovazzo, C.; Cascarano, G.; Marchand, A. P.; Huang, Z.; Kumar, V. S.; Power, T. D. Struct. Chem. 2001, 12, 275-282. (d) Pinkerton, A. A.; Hardie, M. J.; Marchand, A. P.; Kumar, K. A., J. Chem. Crystallogr. 2001, $31(3), 135-141$. 
28. Maya, L.; Moyer, B. A.; Lance, M. J. Vibrational Spectroscopy of Weak Hydroxy Acids Used as Extractants of Sodium Hydroxide into 1-Octanol. Appl. Spectrosc. 2003, 57(2), $238-241$.

29. Kang, H.-A.; Engle, N. L.; Bonnesen, P. V.; Delmau, L. H.; Haverlock, T. J.; Moyer, B. A. Solvent Extraction of Sodium Hydroxide Using Alkylphenols and Fluorinated Alcohols: Understanding the Extraction Mechanism by Equilibrium Modeling. Extended Abstract, Symposium "Environmental and Waste Management: Advancements through the Environmental Management Science Program," 227 $7^{\text {th }}$ American Chemical Society National Meeting, Anaheim, CA, March 28-April 1, 2004; ENVR 30.

30. Levitskaia, T. G.; Lumetta, G. J.; Moyer, B. A. Combined Utilization of Cation Exchanger and Neutral Receptor to Volume Reduction of Alkaline Tank Waste by Separation of Sodium Salts. Extended Abstract, Division of Environmental Chemistry Symposium "Environmental and Waste Management: Advancements through the Environmental Management Science Program," $227^{\text {th }}$ American Chemical Society National Meeting, Anaheim, CA, March 28-April 1, 2004; ENVR 34.

31. Moyer, B. A.; McDowell, W. J.; Ontko, R. J.; Bryan, S. A.; Case, G. N., Complexation of Strontium in the Synergistic Extraction System Dicyclohexano-18-Crown-6, Versatic Acid, Carbon Tetrachloride. Solvent Extr. Ion Exch. 1986, 4, 83-93.

32. Steed, J. W. First- and Second-Sphere Coordination Chemistry of Alkali Metal Crown Ether Complexes. Coord. Chem. Rev. 2001, 215, 171-221.

33. (a) Marcus, Y. The Properties of Organic Liquids that Are Relevant to Their Use as Solvating Agents. Chem. Rev. 1993, 409-416. (b) Reichardt, C. Solvents and Solvent Effects in Organic Chemistry; 2nd ed.; VCH: Weinheim (Federal Republic of Germany), 1990.

34. Lipowski, J.; Kalchenko, V. I.; Suwinska, K.; Simonov, Y. A.; Dvorkin, A. A.; Tsymbal, I. F.; Atamas, L. I.; Markovsky, L. N.; Malinowskii, T. I. Crystal structure of the host-guest complex of trans-meta, meta'-bis-diisopropoxyphosphorylidibenzo-18-crown-6 with phenol. Supramol. Chem. 1996, 7(3), 229-234.

35. Kartsova, L. A.; Markova, O. V.; Amel'chenko, A. I. Effect of 18-crown-6 on the separation selectivity of organic compounds by reversed-phase high-performance liquid chromatography. J. Anal. Chem. 2001, 56(3), 272-277.

36. See for example: (a) Kikuchi, Y.; Arayashiki, Y.; Anada, T. Hydration to benzo-15-crown5, benzo-18-crown-6 and the benzo-18-crown-6-potassium ion complex in the low-polar organic solvents. Anal. Sci. 2001, 17(3), 421-424. (b) Fukuhara, K.; Tachikake, M.; Matsumoto, S.; Matsuura, H. S. Raman-Spectroscopic Study of the Hydrates of 18-Crown6. J. Phys. Chem. 1995, 99(21), 8617-8623. (c) Bryan, S. A.; Willis, R. R.; Moyer, B. A. Hydration of 18-Crown-6 in Carbon Tetrachloride. Infrared Spectral Evidence for an Equilibrium between Monodentate and Bidentate Forms of Bound Water in the 1:1 CrownWater Adduct. J. Phys. Chem. 1990, 94(13), 5230-5233.

37. (a) Marchand, A. P.; Gore, V. K.; Srinivas, G. Synthesis of a Cage-annulated Ditopic Receptor. Heterocycles 2003, 61, 541-550. (b) Marchand, A. P.; Hariprakasha, H. K.; Hazlewood, A.; Krishnudu, K.; Takhi, M. Synthesis of Novel Cage-Annulated Fluoromacrocycles, ARKIVOC (an electronic journal of organic chemistry) 2002, 2(xi), 80-89 (publication date May 13, 2002); URL: http:/ usa.org/ark/journal/Volume2/Part3/Thyagarajan/BT-366J/366J.pdf .

38. Marchand, A. P.; Chong, H.-S.; Kumar, T. P.; Huang, Z.; Alihodzic, S.; Watson, W. H.; Ejsmont, K. Tetrahedron 2002, 58, 10205-10212. 


\section{Information Access}

A complete list of publications, patent application, and presentations for this project is also available as an attachment to this report. A final report for the first three years of the project provides detailed information on early accomplishments of this project. ${ }^{20}$ See also the www home page of the ORNL Chemical Separations Group: URL http://www.ornl.gov/csg. 


\section{PUBLICATION LIST}

\section{Ion Recognition Approach to Volume Reduction of Alkaline Tank Waste by Separation of Sodium Salts

\author{
ENVIRONMENTAL MANAGEMENT SCIENCE PROGRAM \\ PROJECT NO. 81935
}

FY 2002-2004 (Renewal period)

\section{REPRINTS AVAILABLE ON REQUEST}

Dr. Bruce A. Moyer, Chemical Separations Group, Chemical Sciences Division, Oak Ridge National Laboratory, P.O. Box 2008, Bldg. 4500S, MS-6119, Oak Ridge, TN 37831-6119, U.S.A. Ph.: 865-574-6718. FAX: 865574-4939. E-mail: moyerba@ornl.gov. WWW home page: http://www.ornl.gov/sci/casd/csg/csgbro.htm .

Prof. Alan P. Marchand, Department of Chemistry, University of North Texas, NT Station, P.O. Box 305070, Denton, TX 76203-5070. Ph.: 940-565-3823. FAX: 940-565-4318. E-mail: marchand@unt.edu .

Dr. Gregg J. Lumetta, Radiochemical Science and Engineering Group, Pacific Northwest National Laboratory, P.O. Box 999; MSIN P7-22, Richland, WA 99352. Phone: 509-376-6911. Fax: 509-373-9675. E-mail: gregg.lumetta@pnl.gov.

This research was sponsored by the Environmental Management Science Program of the Office of Science, U. S. Department of Energy, under a) Contract Number DE-AC05-00OR22725 with Oak Ridge National Laboratory, managed and operated by UT-Battelle, LLC; b) Contract Number DEAC06-76RLO-1830 with Pacific Northwest National Laboratory, managed and operated by Battelle Memorial Institute; and c) Grant Number DE-FG07-98ER14936 with the University of North Texas.

\section{$\underline{\text { Patent }}$}

Moyer, B. A.; Chambliss, C. K.; Bonnesen, P. V.; Keever, T. J. "Solvent and Process for Recovery of Hydroxide from Aqueous Mixtures," U. S. Patent 6,322,702, Nov. 27, 2001.

\section{$\underline{\text { Publications }}$}

Kang, H-A; Engle, N. L.; Bonnesen, P. V.; Delmau, L. H.; Haverlock, T. J.; Moyer, B.A. An Equilibrium Model of Pseudo-Hydroxide Extraction in the Separation of Sodium Hydroxide from Aqueous Solutions Using Lipophilic Fluorinated Alcohols and Phenols. Sep. Sci. Technol., in press.

Marchand, A. P.; Lai, H.; Deng, B.-L.; CalderÛn, JosÈ, Benzo-containing Cage-annulated Crown Ethers: A New Class of Ag(I) Complexants. Arkivoc 2005, (v), 7-20 (Publication Date 24 June 2004); URL: http://www.arkatusa.org/ark/journal/2005/Fisera/LF-1074E/LF-1074E.pdf.

Sherman, C. L., Brodbelt, J. S.; Marchand, A. P.; Poola, B. Electrospray Ionization Mass Spectrometric Detection of Self-Assembly of a Novel Crown Ether Complex Directed by Pi-stacking Interactions. J. Am. Soc. Mass Spectrom. Manuscript in preparation.

Geldenhuys, W. J.; Malan, S. F.; Bloomquist, J. R.; Marchand, A. P.; Van der Schyf, C. J. "Pharmacology of Polycyclic Cage-derived Compounds", Med. Res. Rev. In press. 
Marchand, A. P.; Brodbelt, J. S.; Mlinaric-Majerski, K. "Synthesis and Evaluation of Metal Cation Complexation Properties of Cage-annulated Macrocyclic Hosts via Electrospray Ionization Mass Spectrometry (ESI-MS)", Kem. Ind. Manuscript submitted.

Kang, H.-A.; Engle, N. L.; Bonnesen, P. V.; Delmau, L. H.; Haverlock, T. J.; Moyer, B. A. Solvent Extraction of Sodium Hydroxide Using Alkylphenols and Fluorinated Alcohols: Understanding the Extraction Mechanism by Equilibrium Modeling. Extended Abstract, Division of Environmental Chemistry Symposium "Environmental and Waste Management: Advancements through the Environmental Management Science Program," $227^{\text {th }}$ American Chemical Society National Meeting, Anaheim, CA, March 28-April 1, 2004; ENVR 30.

Levitskaia, T. G.; Lumetta, G. J.; Moyer, B. A. Combined Utilization of Cation Exchanger and Neutral Receptor to Volume Reduction of Alkaline Tank Waste by Separation of Sodium Salts. Extended Abstract, Division of Environmental Chemistry Symposium "Environmental and Waste Management: Advancements through the Environmental Management Science Program," 227 $7^{\text {th }}$ American Chemical Society National Meeting, Anaheim, CA, March 28-April 1, 2004; ENVR 34.

Marchand, A. P.; Huang, Z.; Lai, H.; Brodbelt, J. S.; Williams, S. Synthesis and Electrospray Ionization Mass Spectrometric Evaluation of the Metal Cation Complexation Behavior of Cage-annulated Azacrown Ethers. Heterocycles 2004, 62, 279-296.

Sherman, C. L.; Brodbelt, J. S.; Srinivas, G.; Sivappa, R.; Marchand, A. P. Electrospray Ionization Mass Spectrometric Study of the Metal Cation Complexation Capabilities of a Novel, Doubly Cage-annulated Molecular Box. Arkivoc (an electronic journal of organic chemistry); 2005, 5(iii), 1-7 (publication date 28 January 2004); URL: $\quad<$ http://www.arkat-usa.org/ark/journal/2005/Rao/AR-957K/957K.pdf $>$ http://www.arkatusa.org/ark/journal/2005/Rao/AR-957K/957K.pdf

Govender, T.; Hariprakasha, H.; Kruger, H. G.; Marchand, A. P. Synthesis and Transport Studies of a New Class of Cage-annulated Chiral Macrocycles. Tetrahedron:Asymmetry 2003, 14, 1553-1559.

Haverlock, T. J.; Bonnesen, P. V.; Moyer, B. A. Separation of NaOH by Solvent Extraction Using Weak Hydroxy Acids. Solvent Extr. Ion Exch. 2003, 21(4), 483-504.

Levitskaia, T. G.; Bonnesen, P. V.; Chambliss, C. K.; Moyer, B. A. Synergistic Pseudo-Hydroxide Extraction: Synergism and Anion Selectivity in Sodium Extraction Using a Crown Ether and a Series of Weak Lipophlilic Acids. Anal. Chem. 2003, 75(3), 405-412.

Marchand, A. P.; Gore, V. K.; Srinivas, G. Synthesis of a Cage-annulated Ditopic Receptor. Heterocycles 2003, $61,541-550$.

Marchand, A. P.; Hazlewood, A.; Huang, Z. L.; Vadlakonda, S. K.; Rocha, J. D. R.; Power, T. D.; MlinaricMajerski, K.; Klaic, L.; Kragol, G.; Bryan, J. C., Stabilization of a K ${ }^{+}$-(bis-cage-annulated 20-crown-6) complex by bidentate picrate. Struct. Chem. 2003, 14, (3), 279-288.

Maya, L.; Moyer, B. A.; Lance, M. J. Vibrational Spectroscopy of Weak Hydroxy Acids Used as Extractants of Sodium Hydroxide into 1-Octanol. Appl. Spectrosc. 2003, 57(2), 238-241.

Ross, N. A.; Bartsch, R. A.; Marchand, A. P. High-intensity Ultrasound-promoted Reformatsky Reactions of Pentacyclo[5.4.0.0 $2,6.0^{3,10} .0^{5,9}$ ] undecane-8,11-dione. Arkivoc (an electronic journal of organic chemistry) 2003, Part 12, 27-30.

Williams, S. M.; Brodbelt, J. S.; Huang, Z.; Lai, H.; Marchand, A. P. Complexation of Silver and Co-recovered Metals with Novel Aza-crown Ether Macrocycles by Electrospray Ionization Mass Spectrometry, Analyst 2003, 128, 1352-1359.

Haverlock, T. J.; Bonnesen, P. V.; Brown, G. M.; Chambliss, C. K.; Levitskaia, T. G.; Moyer, B. A. Separation of $\mathrm{NaOH}$ from Salts by Weak Hydroxy Acids. Proc. Internat. Solvent Extraction Conf. (ISEC 2002), Cape Town, 
S. Africa, Mar. 17-21, 2002, Vol. 1, K. C. Sole P. M. Cole, J. S. Preston, D. J. Robinson, Eds., Chris van Rensburg Publications, Melville, South Africa, 2002; pp. 396-401.

Marchand, A. P.; Cal, D.; Mlinaric-Majerski, K.; Ejsmont, K.; Watson, W. H. Cage-Annulated Thiacrown Ethers and Thiacryptands. J. Chem. Crystallogr. 2002, 32, 447-463.

Marchand, A. P.; Chong, H.-S.; Kumar, T. P.; Huang, Z.; Alihodzic, S.; Watson, W. H.; Ejsmont, K. Synthesis and Alkali Metal Picrate Extraction Studies of Lower Rim Functionalized p-tert-Butylcalix[4]arene Cage-Annulated Crown Ethers. Tetrahedron 2002, 58, 10205-10212.

Marchand, A. P.; Hariprakasha, H. K.; Hazlewood, A.; Krishnudu, K.; Takhi, M. Synthesis of Novel CageAnnulated Fluoromacrocycles. ARKIVOC (an electronic journal of organic chemistry) 2002, 2(xi), 80-89 (publication date May 13, 2002); URL: http://www.arkat-usa.org/ark/journal/Volume2/Part3/Thyagarajan/BT366J/366J.pdf .

Williams, S. M.; Brodbelt, J. S.; Marchand, A. P.; Cal, D.; Mlinaric-Majerski, K. Metal Complexation of Thiacrown Ether Macrocycles by Electrospray Ionization Mass Spectrometry. Anal. Chem. 2002, 74(17), 4423-4433.

Marchand, A. P.; Huang, Z.; Chen, Z.; Hariprakasha, H. K.; Namboothiri, I. N. N.; Brodbelt, J. S.; Reyzer, M. L., Synthesis, Alkali Metal Picrate Extraction, and Alkali Metal Cation Binding Selectivities of Some New CageAnnulated Polyoxamacrocyclic Crown Ethers. J. Heterocyclic Chem. 2001, 38(6), 1361-1368.

Pinkerton, A. A.; Hardie, M. J.; Marchand, A. P.; Kumar, K. A., Synthesis of an Unusual, Cage-Functionalized Molecular Cleft.J. Chem. Crystallogr. 2001, 31(3), 135-141.

\section{Miscellaneous Reports and Summaries}

Moyer, B. A.; Lumetta, G. J.; Marchand, A. P.; Bonnesen, P. V.; Bryan, J. C.; Delmau, L. H.; Engle, N. L.; Gadthula, S.; Gore, V. K.; Haverlock, T. J.; Huang, Z.; Kang, H.-A.; Levitskaia, T. G.; Maya, L.; Sivappa, R.; Tirunahari, P. K. Ion Recognition Approach to Volume Reduction of Alkaline Tank Waste by Separation and Recycle of Sodium Hydroxide and Sodium Nitrate. Environmental Management Science Program Annual Report; Oak Ridge National Laboratory: Oak Ridge, Tennessee, June 19, 2003; available on the World Wide Web site of the USDOE Office of Environmental Management, URL http://emsp.em.doe.gov/ .

Moyer, B. A.; Lumetta, G. J.; Marchand, A. P. Ion Recognition Approach to Volume Reduction of Alkaline Tank Waste by Separation and Recycle of Sodium Hydroxide and Sodium Nitrate. Environmental Management Science Program Annual Report; Oak Ridge National Laboratory: Oak Ridge, Tennessee, June 21, 2002; available on the World Wide Web site of the USDOE Office of Environmental Management, URL http://emsp.em.doe.gov/ .

Moyer, B. A.; Bonnesen, P. V.; Brown, G. M.; Bryan, J. C.; Chambliss, C. K.; Haverlock, T. J.; Levitskaia, T. G.; Marchand, A. P. Ion Recognition Approach to Volume Reduction of Alkaline Tank Waste by Separation and Recycle of Sodium Hydroxide and Sodium Nitrate; Environmental Management Science Program Fiscal Year 1998 Annual Report; Oak Ridge National Laboratory: Oak Ridge, Tennessee, Aug. 3, 2001; available on the World Wide Web site of the USDOE Office of Environmental Management, URL http://emsp.em.doe.gov/ .

\section{Presentations (Presenter underlined)}

Levitskaia, T. G.; Lumetta, G. J.; Moyer, B. A. Combined Utilization of Cation Exchanger and Neutral Receptor to Volume Reduction of Alkaline Tank Waste by Separation of Sodium Salts. $227^{\text {th }}$ American Chemical Society National Meeting, Anaheim, CA, March 28-April 1, 2004.

Kang, H.-A.; Engle, N. L.; Bonnesen, P. V.; Delmau, L. H.; Haverlock, T. J.; Moyer, B. A. Solvent Extraction of Sodium Hydroxide Using Alkylphenols and Fluorinated Alcohols: Understanding the Extraction Mechanism by Equilibrium Modeling, 227 $7^{\text {th }}$ American Chemical Society National Meeting, Anaheim, CA, March 28-April 1, 2004. 
Levitskaia, T. G.; Lumetta, G. J.; Moyer, B. A. Ion Recognition Approach to Volume Reduction of Alkaline Tank Waste by Separation of Sodium Salts. Thirteenth Symposium on Separation Science \& Technology for Energy Applications, Gatlinburg, TN, October 27-30, 2003 (CONTRIBUTED—ORAL PRESENTATION).

Kang, H-A; Engle, N. L.; Bonnesen, P. V.; Delmau, L. H.; Haverlock, T. J.; Moyer, B.A. An Equilibrium Model of Pseudo-Hydroxide Extraction in the Separation of Sodium Hydroxide from Aqueous Solutions Using Lipophilic Fluorinated Alcohols and Phenols. Thirteenth Symposium on Separation Science \& Technology for Energy Applications, Gatlinburg, TN, October 27-30, 2003 (CONTRIBUTED_POSTER).

Moyer, B. A.; Bonnesen, P. V.; Delmau, L. H.; Engle, N. L.; Haverlock, T. J.; Kang, H.-A.; Levitskaia, T. G.; Lumetta, G. J.; Marchand, A. P.; Maya, L. "Ion Recognition Approach to Volume Reduction of Alkaline Tank Waste by Separation of Sodium Salts," FY2003 Environmental Management Science Program Principal Investigator Workshop, Pacific Northwest National Laboratory, Richland, WA, May 6-7, 2003 (INVITED - ORAL PRESENTATION).

Atim, S.; Romanski, J.; Marchand, A. P. "Synthesis of Fluorescent-labeled Cage-annulated Crown Ethers. Potential New Host Systems for Selective Complexation and Transport of Metal Cations," ACS-DFW Meeting-inMiniature, Texas A\&M University at Commerce, Commerce, TX, Apr. 25, 2003; Paper No. G-20 (CONTRIBUTED).

Lai H.; Marchand, A. P. "Design and Synthesis of Novel Cage-Functionalized Crown Ethers: A New Class of Ag(I) Complexants," ACS-DFW Meeting-in-Miniature, Texas A\&M University at Commerce, Commerce, TX, Apr. 25, 2003. Paper No. G-21 (CONTRIBUTED).

Poola, B.; Marchand, A. P. "Synthesis and Host-Guest Complexation Properties of Quinoxaline-functionalized Cage-annulated Crown Ethers," ACS-DFW Meeting-in-Miniature, Texas A\&M University at Commerce, Commerce, TX, Apr. 25, 2003; Paper No. G-19 (CONTRIBUTED).

Marchand, A. P.; Huang, Z.; Lai, H.; Brodbelt, J. S.; Williams, S. "ESI-MS Evaluation of the Metal Cation Complexation Behavior of Cage-Annulated Aza Crown Ethers," 225th National Meeting of the American Chemical Society, New Orleans, LA, Mar. 23-27, 2003; Paper No. ORGN-716 (CONTRIBUTED-ORAL PRESENTATION).

Marchand, A. P.; Ji, M.; Deng, B.-L.; Chong, H.-S. "Synthesis of Optically Active, Cage-Annulated Crown Ethers: Potential New Agents for Enantioselective Recognition of Chiral Ammonium Salts," 4th Florida Conference on Heterocyclic Chemistry, Gainesville, FL, Mar. 10-12, 2003 (CONTRIBUTED-POSTER PRESENTATION).

Moyer, B. A.; Bonnesen, P. V.; Bryan, J. C.; Delmau, L. H.; Haverlock, T. J.; Kavallieratos, K.; Levitskaia, T. G.; Sloop, F. V., Jr. "Fundamental Principles and Applications of Host-Guest Chemistry in Liquid-Liquid Separation Systems," Technical University of Dresden, Dresden, Germany, Nov. 11, 2002 (INVITED — ORAL PRESENTATION).

Moyer, B. A.; Bonnesen, P. V.; Bryan, J. C.; Delmau, L. H.; Haverlock, T. J.; Kavallieratos, K.; Levitskaia, T. G.; Sloop, F. V., Jr. "Fundamental Principles and Applications of Host-Guest Chemistry in Liquid-Liquid Separation Systems," DECHEMA Symposium "Supramolecular Strategies for Selective Solvent Extraction Processes," Frankfurt am Main, Germany, Nov. 8, 2002 (INVITED—ORAL PRESENTATION).

Moyer, B. A.; Bonnesen, P. V.; Bryan, J. C.; Delmau, L. H.; Haverlock, T. J.; Kavallieratos, K.; Levitskaia, T. G.; Sloop, F. V., Jr. "Strategies for Accommodating the Anion in the Extraction of Alkali Metal Salts and an Application in Nuclear Waste Cleanup," Royal Society of Chemistry Symposium "Co-ordination Chemistry in Action," Univ. of Edinburgh, Edinburgh, Scotland, United Kingdom, Nov. 6, 2002 (INVITED - ORAL PRESENTATION).

Marchand, A. P.; Brodbelt, J. S.; Mlinaric-Majerski, K.; Watson, W. H. "Cage Annulated Crown Ethers and Cryptands: New Agents for Selective Cation Complexation and for Enantioselective Recognition of Chiral Ammonium Salts," 2002 Southwest Regional Meeting of the American Chemical Society, Austin, TX, November 3-6, 2002 (INVITED - PLENARY LECTURE in the Symposium on Self Assembly, Molecular Recognition, and Host-Guest Interactions in Organic Systems) 
Moyer B. A.; Lumetta, G. J., "Solvent Extraction Technologies for Mission Acceleration Initiative: NaOH Removal \& Tc, Tc Removal," Mission Acceleration Initiative Technology Demonstration Workshop, Pacific Northwest National Laboratory, Richland, WA, Apr. 2-3, 2002 (INVITED—ORAL PRESENTATION).

Moyer, B. A.; Bonnesen, P. V.; Chambliss, C. K.; Haverlock, T. J.; Levitskaia, T. G., "Separation of NaOH from Salts by Weak Hydroxy Acids," Internat. Solvent Extr. Conf. ISEC '02, Cape Town, South Africa, Mar. 17-21, 2002 (CONTRIBUTED_ORAL KEYNOTE PRESENTATION).

Moyer, B. A.; Bonnesen, P. V.; Bryan, J. C.; Delmau, L. H.; Engle, N. L.; Haverlock, T. J.; Levitskaia, T. G.; Sachleben, R. A.; Sloop, F. V., Jr., "Ion-Recognition Approaches to the Treatment of Alkaline High-Level Waste by Liquid-Liquid Extraction," Dept. of Chemistry Seminar, Univ. of California, Berkeley, CA, Feb. 1 , 2002 (INVITED_ORAL PRESENTATION).

Moyer, B. A.; Bonnesen, P. V.; Marchand, A. P.; Lumetta, G. J., "Ion Recognition Approach to Volume Reduction of Alkaline Tank Waste by Separation of Sodium Salts," EMSP High-Level Waste Workshop, Richland, Washington, Nov. 7-9, 2001 (INVITED_ORAL PRESENTATION).

Moyer, B. A.; Lumetta, G. J., "Concepts in Sodium Separation for HLW Volume Reduction," EMSP High-Level Waste Workshop, Special Discussion Session, Richland Washington, Nov. 7-9, 2001 (INVITED-ORAL PRESENTATION). 


\title{
PUBLICATION LIST
}

\section{Ion Recognition Approach to Volume Reduction of Alkaline Tank Waste by Separation and Recycle of Sodium Hydroxide and Sodium Nitrate}

\author{
ENVIRONMENTAL MANAGEMENT SCIENCE PROGRAM \\ PROJECT NO. 65339
}

FY 1998-2001

September 1998 to September 2001

\section{REPRINTS AVAILABLE ON REQUEST.}

Dr. Bruce A. Moyer, Chemical Separations Group, Chemical Sciences Division, Oak Ridge National Laboratory, P.O. Box 2008, Bldg. 4500S, MS-6119, Oak Ridge, TN 37831-6119, U.S.A. Ph.: 865-574-6718. FAX: 865574-4939. E-mail: moyerba@ornl.gov. WWW home page: http://www.ornl.gov/csg .

Prof. Alan P. Marchand, Department of Chemistry, University of North Texas, NT Station, P.O. Box 305070, Denton, TX 76203-5070. Ph.: 940-369-7226. FAX: 940-369-7374. E-mail: marchand@unt.edu .

\begin{abstract}
This research was sponsored by the Environmental Management Science Program of the Offices of Science and Environmental Management, U. S. Department of Energy, under a) contract number DE-AC05-00OR22725 with Oak Ridge National Laboratory, managed and operated by UTBattelle, LLC, and b) Grant number DE-FG07-98ER14936 with the University of North Texas.
\end{abstract}

\section{$\underline{\text { Publications }}$}

S. M. Blair, J. S. Brodbelt, A. P. Marchand, H.-S. Chong, and S. Alihodzic, "Evaluation of Alkali Metal Binding Selectivities of Caged Aza-Crown Ether Ligands by Electrospray Ionization Quadrupole Ion Trap Mass Spectrometry," J. Am. Soc. Mass Spectrom., 11, 884-891 (2000).

S. M. Blair, J. S. Brodbelt, A. P. Marchand, K. A. Kumar, and H.-S. Chong, "Evaluation of Binding Selectivities of Caged Crown Ligands Towards Heavy Metals by Electrospray Ionization/Quadrupole Ion Trap Mass Spectrometry," Anal. Chem., 72, 2433-2445 (2000).

J. C. Bryan, A. P. Marchand, and A. Hazlewood, “N,N'-Diacetyl-1,13-diaza-24-crown-8,” Acta Crystallogr. E, 57, o13-15 (2001).

J. C. Bryan, K. Mlinaric-Majerski, G. Kragol, and A. P. Marchand, "Crystal Structure of 1,3-Hydroxymethyl-2oxaadamantane, $\mathrm{C}_{11} \mathrm{H}_{18} \mathrm{O}_{3}$," Z. Kristallogr., 216, 277-279 (2001). Joint sponsorship with the Robert A. Welch Foundation, the Texas Advanced Technology Program, and the Ministry of Science and Technology of the Republic of Croatia.

J. C. Bryan, T. G. Levitskaia, C. Giacovazzo, G. Cascarano, A. P. Marchand, Z. Huang, V. S. Kumar, and T. D. Power, "Synthesis, Alkali Metal Picrate Extraction Properties, and X-ray Crystal Structure of a Novel, CageAnnulated 18-Crown-6 Host," Struct. Chem. 12, 275-282 (2001) (Invited).

C. K. Chambliss, T. J. Haverlock, P. V. Bonnesen, N. L. Engle, and B. A. Moyer, "Selective Separation of Hydroxide from Alkaline Media by Liquid-Liquid Extraction with Weak Hydroxy Acids," Environ. Sci. Technol. 36, 1861-1867 (2002).

T. Hayashita, T. Higuchi, H. Sawano, A. P. Marchand, K. A. Kumar, S. G. Bott, K. Mlinaric-Majerski, T. Sumanovac, N. S. Elkarim, H.-S. Hwang, G. Talanova, and R. A. Bartsch, "Molecular Design of Lipophilic Disalicylic Acid Compounds with Varying Spacers for Selective Lead(II) Extraction," Talanta, 52, 385-396 (2000). 
T. G. Levitskaia, B. A. Moyer, P. V. Bonnesen, A. P. Marchand, K. Krishnudu, Z. Chen, Z. Huang, H. G. Kruger, and A. S. McKim "Novel Approach to Sodium Hydroxide Separation: Synergistic Pseudo Hydroxide Extraction by a Fluorinated Alcohol and Cage-Functionalized Crown Ethers," J. Am. Chem. Soc., 123, 12099$12100(2001)$.

A. T. Macias, K. A. Kumar, A. P. Marchand, and J. D. Evanseck, "Synthesis and Inclusion Complexation Studies of a Novel and Selective Molecular Receptor for 1,4-Disubstituted Benzenes and 4,4'-Disubstituted Biphenyls," $J$. Org. Chem., 65, 2083-2089 (2000).

A. P. Marchand and H.-S. Chong, "Synthesis and Alkali Metal Picrate Extraction Capabilities of Novel, CageFuntionalized Diaza(17-crown-5) Ethers," Tetrahedron, 55, 9697-9706 (1999).

A. P. Marchand, H.-S. Chong, S. Alihodzic, W. H. Watson, and S. G. Bodige, "Synthesis and Alkali Metal Picrate Extraction Capabilities of Novel, Cage-functionalized, Pyridine-containing Crown Ethers and Cryptands," Tetrahedron, 55, 9687-9786 (1999).

A. P. Marchand, H.-S. Chong, M. Takhi, and T. D. Power, "Synthesis and Alkali Metal Picrate Extraction Studies of p-tert-Butylcalix[4]arene Crown Ethers Bridged at the Lower Rim with Pyridyl Units," Tetrahedron, 56, 3121$3126(2000)$.

A. P. Marchand, H.-S. Chong, M. Takhi, W. H. Watson, and S. G. Bodige, "Synthesis and Extraction Studies of an Unusual Cage-Funtionalized Cryptand," Heterocycles, 54, 151-158 (2001).

A. P. Marchand, K. A. Kumar, A. S. McKim, S. Alihodzic, H.-S. Chong, K. Krishnudu, and M. Takhi, "Novel Cage-Annulated Crown Ethers, Cryptands, and Molecular Boxes: A New Class of Ionophores for Selective Ion Complexation," Kem. Ind. 50, 129-138 (2001).

A. P. Marchand, M. Takhi, V. S. Kumar, K. Krishnudu, and B. Ganguly, "Synthesis of Novel Chiral, Cageannulated Macrocycles," ARKIVOC, July, 2001; URL: http://www.arkat.org/arkat/journal/Issue10/ms3/ms3.htm.

B. A. Moyer, P. V. Bonnesen, C. K. Chambliss, T. J. Haverlock, A. P. Marchand, H-S. Chong, A. S. McKim, K. Krishnudu, K. S. Ravikumar, V. S. Kumar, and M. Takhi, "Use of Cage-Functionalized Macrocycles and Fluorinated Alcohols in the Liquid-Liquid Extraction of $\mathrm{NaOH}$ and other Sodium Salts: Strategies Toward WasteVolume Reduction," in Nuclear Site Remediation: First Accomplishments of the Environmental Science Program, ACS Symposium Series, Vol. 778, P. G. Eller and W. R. Heineman, Eds., American Chemical Society, Washington, DC, 2001; pp. 114-132 (Invited).

M. L. Reyzer, J. S. Brodbelt, A. P. Marchand, Z. Chen, Z. Huang, and I. N. N. Namboothiri, "Determination of Alkali Metal Binding Selectivities of Caged Crown Ligands by Electrospray Ionization Quadrupole Ion Trap Mass Spectrometry," Int. J. Mass Spectrom. 204, 133-142 (2001).

W. H. Watson, S. G. Bodige, A. P. Marchand, and H.-S. Chong, "A One-Pot Synthesis Of Cage-Functionalized, Ketal-Containing Crown Ethers," Struct. Chem. 11, 257-260 (2000).

\section{Miscellaneous Reports and Summaries}

A. P. Marchand, "Ion Recognition Approach to Volume Reduction of Alkaline Tank Waste by Separation and Recycle of Sodium Hydroxide and Sodium Nitrate," Environmental Management Science Program Fiscal Year 1998 Awards Annual Progress Report, June 3, 1999; Letter-form report sent to Ms. Kara L. Twitchell, Procurement Services Division, U. S. Department of Energy, Idaho Operations Office.

B. A. Moyer, P. V. Bonnesen, G. M. Brown, T. J. Haverlock, and T. G. Levitskaia, "Solvent Extraction Approach to Sodium Hydroxide Recycle from Alkaline Tank Waste. Results from EM Science Program Project No. 65339," Technology description and progress report provided to CH2MHILL, Nov., 2000.

B. A. Moyer, P. V. Bonnesen, G. M. Brown, J. C. Bryan, C. K. Chambliss, T. J. Haverlock, T. G. Levitskaia, A. P. Marchand, H.-S. Chong, H. K. Hariprakasha, K. Krishnudu, V. S. Kumar, A. S. McKim, K. S. Ravikumar, M. Takhi, "Ion Recognition Approach to Volume Reduction of Alkaline Tank Waste by Separation and Recycle of Sodium Hydroxide and Sodium Nitrate," Environmental Management Science Program Fiscal Year 1998 Awards 
Annual Progress Report, Jun., 2000; posted on the WWW site of the USDOE Environmental Management Science Program http://emsp.em.doe.gov/

B. A. Moyer, P. V. Bonnesen, J. C. Bryan, C. K. Chambliss, T. J. Haverlock, T. G. Levitskaia, A. P. Marchand, H.-S. Chong, A. S. McKim, K. Krishnudu, K. S. Ravikumar, V. S. Kumar, M. Takhi, and H. K. Hariprakasha, "Ion Recognition Approach to Volume Reduction of Alkaline Tank Waste by Separation and Recycle of Sodium Hydroxide and Sodium Nitrate," Environmental Management Science Program Fiscal Year 1998 Awards Annual Project Summary, Apr. 25, 2000; available on the World Wide Web site of the USDOE Office of Environmental Managementhttp://emsp.em.doe.gov/

B. A. Moyer, C. K. Chambliss, T. J. Haverlock, P. V. Bonnesen, J. C. Bryan, and A. P. Marchand, "Ion Recognition Approach to Volume Reduction of Alkaline Tank Waste by Separation and Recycle of Sodium Hydroxide and Sodium Nitrate," Environmental Management Science Program Fiscal Year 1998 Awards Annual Progress Report, Jun. 15, 1999; available on the World Wide Web site of the USDOE Office of Environmental Management http://emsp.em.doe.gov/

\section{Presentations}

T. G. Levitskaia, B. A. Moyer, P. V. Bonnesen, A. P. Marchand, K. Krishnudu, Z. Chen, Z. Huang, H. G. Kruger, and A. S. McKim, "Novel Approach to $\mathrm{NaOH}$ Separation: Synergistic Pseudo-Hydroxide Extraction by a Fluorinated Alcohol and Cage-Functionalized Crown Ethers," ACS National Meeting, Chicago, IL, Aug. 26-30, 2001 (CONTRIBUTED - ORAL PRESENTATION).

A. P. Marchand, T. D. Power, B. A. Moyer, T. G. Levitskaia, P. V. Bonnesen, and J. C. Bryan, "Ion-Pair Extraction by Using Cage-Functionalized Hosts: Strategy for Selective Extraction of $\mathrm{NaOH}$ from Wastes," ACS National Meeting, Chicago, IL, Aug. 26-30, 2001 (CONTRIBUTED - ORAL PRESENTATION).

B. A. Moyer, P. V. Bonnesen,, G. M. Brown, J. C. Bryan, L. H. Delmau, T. J. Haverlock, T. G. Levitskaia, and F. J. Sloop, "Liquid-Liquid Extraction Approaches to the Treatment of Alkaline High-Level Waste," ACS National Meeting, Chicago, IL, Aug. 26-30, 2001 (INVITED - KEYNOTE LECTURE).

A. P. Marchand, "Evaluation of Binding Selectivities of Cage-Annulated Crown Ligands Toward Alkali Metal and Heavy Metal Cations by Electrospray Ionization/Quadrupole Ion Trap Mass Spectrometry," Rudjer Boskovic Institute, Zagreb, Croatia, June 20, 2001 (Colloquium -INVITED).

A. P. Marchand, "From Cage Compounds to Molecular Clefts. Novel Cage-Annulated Crown Ethers, Cryptands, and Molecular Boxes: A New Class of Ionophores for Selective Ion Complexation," Department of Chemistry, Rutgers University, Newark, NJ, April 27, 2001 (Departmental seminar speaker - INVITED).

A. P. Marchand, "From Cage Compounds to Molecular Clefts. Novel Cage-Annulated Crown Ethers, Cryptands, and Molecular Boxes: A New Class of Ionophores for Selective Ion Complexation," Department of Chemistry, Rutgers University, New Brunswick, NJ, April 26, 2001 (Departmental seminar speaker - INVITED).

P. V. Bonnesen, L. H. Delmau, N. L. Engle, T. J. Haverlock, T. G. Levitskaia, B. A. Moyer, "Application of Fluorinated Alcohols in Metal Ion Solvent Extraction Processes for Nuclear Waste Disposal and Environmental Remediation," $221^{\text {st }}$ Meeting of the ACS, San Diego, CA, Apr. 1-5, 2001 (CONTRIBUTED - ORAL PRESENTATION).

A. P. Marchand, Z. Huang, Z. Chen, H. K. Hariprakasha, I. N. N. Namboothiri, J. S. Brodbelt, and M. L. Reyzer, "Synthesis, Alkali Metal Picrate Extraction, and Alkali Metal Cation Binding Selectivities of Some New CageAnnulated Polyoxamacrocyclic Crown Ethers," 2nd Florida Heterocyclic Conference, University of Florida, Gainesville, FL, March 7-9, 2001 (CONTRIBUTED - poster presentation).

B. A. Moyer, P. V. Bonnesen, C. K. Chambliss, G. M. Brown, and T. J. Haverlock, "Liquid-Liquid Separation of $\mathrm{NaOH}$ Using Fluorinated Alcohols and Phenols," Pacifichem 2000, Honolulu, HI, Dec. 14-19, 2000 (INVITED ORAL PRESENTATION in the symposium "Separations Science: Trends for the New Century").

Alan P. Marchand, "Synthesis and Chemistry of Unnatural Products: From Cage Compounds to Molecular Clefts. Novel Cage-Annulated Crown Ethers, Cryptands, and Molecular Boxes: A New Class of Ionophores for Selective 
Ion Complexation," Department of Chemistry, University of Texas at San Antonio (UTSA), San Antonio, TX, November 3, 2000 (INVITED - Departmental seminar speaker).

A. P. Marchand, "Novel Cage-Annulated Crown Ethers, Cryptands, and Molecular Boxes: A New Class of Ionophores for Selective Ion Complexation," Department of Chemistry, New Mexico Tech, Soccorro, NM, October 13, 2000 (INVITED - Departmental seminar speaker).

Alan P. Marchand, "Crown Ethers, Cryptands, and Molecular Boxes Derived from Function-alized Pentacycloundecanediones. A New Class of Ionophores for Selective Ion Complexation," Chemical Separations Group, Chemical \& Analytical Sciences Division, Oak Ridge National Laboratory, Oak Ridge, TN, October 2, 2000 (INVITED).

A. P. Marchand, K. A. Kumar, A. S. McKim, S. Alihodzic, H.-S. Chong, K. Krishnudu, M. Takhi, K. MlinaricMajerski, G. Kragol, and T. Sumanovac, "Crown Ethers, Cryptands, and Molecular Boxes Derived from Functionalized Pentacyclo[5.4.0.0<2,6>.0<3,10>.0<5,9>] undecane-4,11-diones. A New Class of Ionophores for Selective Ion Complexation," 80th Annual Meeting of the Polish Chemical Society, September 11-15, 2000, Session No. 1, Paper No. W-8. (INVITED - PLENARY LECTURE)

Alan P. Marchand, Mohamed Takhi, V. Satish Kumar, Kasireddy Krishnudu, Bishwajit Ganguly, Jennifer S. Brodbelt, and Michelle Reyzer, "Novel Chiral, Cage-Annulated Macrocycles," 220th National Meeting of the American Chemical Society, Washington, DC, August 20-25, 2000, Paper No. ORGN-478 (CONTRIBUTED - oral presentation).

A. P. Marchand, K. A. Kumar, A. S. McKim, S. Alihodzic, H.-S. Chong, K. Krishnudu, M. Takhi, K. MlinaricMajerski, G. Kragol, and T. Sumanovac, "Novel Cage-Annulated Crown Ethers, Cryptands, and Molecular Boxes: A New Class of Ionophores for Selective Ion Complexation," Central European Chemical Meeting (CECM-1), Varazdin, Croatia, June 14-17, 2000 (INVITED - PLENARY LECTURE).

Alan P. Marchand, "Synthesis and Chemistry of Unnatural Products: From Cage Compounds to Molecular Clefts. Novel Cage-Annulated Crown Ethers, Cryptands, and Molecular Boxes: A New Class of Ionophores for Selective Ion Complexation," Department of Chemistry, Texas Tech University, Lubbock, TX, May 3, 2000 (INVITED Departmental seminar speaker).

A. P. Marchand, A. S. McKim, H.-S. Chong, K. Krishnudu, M. Takhi, V. S. Kumar, Z. Chen, and Z. Huang, "Cage-functionalized, Nitrogen-containing Crown Ethers and Podands; Potential New Host Systems for Extraction of $\mathrm{NaOH}$ from Wastes," EMSP Workshop, sponsored by the U. S. Department of Energy, Atlanta, GA, April 2527, 2000 (POSTER - INVITED).

B. A. Moyer, P. V. Bonnesen, C. K. Chambliss, T. J. Haverlock, A. P. Marchand, H-S Chong, A. S. McKim, K. Krishnudu, K. S. Ravikumar, V. S. Kumar, M. Takhi, and H. K. Hariprakasha, "Strategies Toward Reduction of High-Level Waste Volume: Use of Fluorinated Alcohols and Cage-Functionalized Macrocycles in the Extraction of $\mathrm{NaOH}$," Second Environmental Management Science Program National Workshop, Atlanta, GA, April 25-27, 2000 (INVITED ORAL PRESENTATION AND POSTER).

Z. Chen and A. P. Marchand, "Synthesis and Alkali Metal Picrate Extraction Capabilities of Cage-annulated Crown- and Azacrown Ethers. Part I.," 33rd Annual ACS-DFW Meeting-in-Miniature, University of North Texas, Denton, TX, April 15, 2000, Graduate Section; Paper No. G-03 (CONTRIBUTED - ORAL PRESENTATION).

A. Hazlewood and A. P. Marchand, "Synthesis and Properties of Novel, Cage-functionalized Macrocyclic Crown Ethers and Cryptands. Part I.," 33rd Annual ACS-DFW Meeting-in-Miniature, University of North Texas, Denton, TX, April 15, 2000, Graduate Section; Paper No. G-01 (CONTRIBUTED - ORAL PRESENTATION).

Z. Huang and A. P. Marchand, "Synthesis and Alkali Metal Picrate Extraction Capabilities of Cage-annulated Crown- and Azacrown Ethers. Part I.," 33rd Annual ACS-DFW Meeting-in-Miniature, University of North Texas, Denton, TX, April 15, 2000, Graduate Section; Paper No. G-02 (CONTRIBUTED - ORAL PRESENTATION).

M. P. Unni and A. P. Marchand, "Synthesis and Properties of Novel, Cage-functionalized Macrocyclic Crown Ethers and Cryptands. Part II.," 33rd Annual ACS-DFW Meeting-in-Miniature, University of North Texas, Denton, TX, April 15, 2000, Undergraduate Section, Paper No. U-03 (CONTRIBUTED - ORAL PRESENTATION). 
A. T. Macias, K. A. Kumar, A. P. Marchand, and J. D. Evanseck, "Synthesis and Inclusion Complexation Studies of a Novel Molecular Receptor for 1,4-Disubstituted Benzenes and 4,4'-Disubstituted Biphenyls," 219th National Meeting of the American Chemical Society, San Francisco, CA, March 26-30, 2000, Paper No. COMP-103 (CONTRIBUTED - POSTER).

A. P. Marchand, "Novel Cage-Annulated Crown Ethers, Cryptands, and Molecular Boxes: A New Class of Ionophores for Selective Ion Complexation," Department of Chemistry, Southern Methodist University, Dallas, TX, February 28, 2000 (INVITED - DEPARTMENTAL SEMINAR).

B. A. Moyer, P.V. Bonnesen, C. K. Chambliss, T. J. Haverlock, A. P. Marchand, H.-S. Chong, A. S. McKim, K. Krishnudu, K. S. Ravikumar, V. S. Kumar, and M. Takhi, "Ion-Pair Recognition: Targeting NaOH," Dept. of Chemistry, Univ. of North TX, Jan. 19, 2000 (DEPARTMENTAL SEMINAR).

S. M. Blair, J. S. Brodbelt, A. P. Marchand, H.-S. Chong, K. A. Kumar, and S. Alihodzic, "Evaluation of Binding Selectivities of Caged Crown Ligands Toward Metal Cations By Using Electrospray Ionization Quadrupole Ion Trap Mass Spectro-metry," 218th National Meeting of the American Chemical Society, New Orleans, LA, August 22-26, 1999, Paper No. NUCL-080 (INVITED - POSTER PRESENTATION in the Symposium on "First Accomplishments of the Environmental Management Science Program").

S. M. Blair, J. S. Brodbelt, A. P. Marchand, H.-S. Chong, K. A. Kumar, and S. Alihodzic, "Evaluation of Binding Selectivities of Caged Crown Ligands Toward Metal Cations By Using Electrospray Ionization Quadrupole Ion Trap Mass Spectrometry," 218th National Meeting of the American Chemical Society, New Orleans, LA, August 22-26, 1999, (INVITED - POSTER PRESENTATION in the Sci-Mix that followed the Symposium on "First Accomplishments of the Environmental Management Science Program").

A. P. Marchand, H.-S. Chong, S. Alihodzic, W. H. Watson, and S. G. Bodige, "Synthesis and Alkali Metal Picrate Extraction Capabilities of Novel, Cage-functionalized, Pyridine-containing Crown Ethers and Cryptands," 218th National Meeting of the American Chemical Society, New Orleans, LA, August 22-26, 1999, Paper No. NUCL-081 (INVITED - POSTER PRESENTATION in the Symposium on "First Accomplishments of the Environmental Management Science Program").

A. P. Marchand, H.-S. Chong, A. S. McKim, K. Krishnudu, K. S. Ravikumar, V. S. Kumar, and M. Takhi, B. A. Moyer, C. K. Chambliss, P. V. Bonnesen, and J. C. Bryan, "Cage-functionalized, Nitrogen-containing Macrocycles and Podands; Potential New Host Systems for Extraction of $\mathrm{NaOH}$ from Wastes," 218th National Meeting of the American Chemical Society, New Orleans, LA, August 22-26, 1999, Paper No. NUCL-108 (INVITED - ORAL PRESENTATION in the Symposium on "First Accomplishments of the Environmental Management Science Program").

A. P. Marchand, "Crown Ethers, Cryptands, and Molecular Boxes Derived from Functionalized Pentacyclo[5.4.0.02,6.03,10.05,9] undecane-4,11-diones. A New Class of Ionophores for Selective Ion Complexation," PLIVA Pharmaceutical Company, Zagreb, Croatia, June 18, 1999, (INVITED - ORAL PRESENTATION).

S. M. Blair, J. S. Brodbelt, A. P. Marchand, H.-S. Chong, K. A. Kumar, and S. Alihodzic, "Evaluation of Binding Selectivities of Caged Crown Ligands Toward Metal Cations By Using Electrospray Ionization Quadrupole Ion Trap Mass Spectrometry," Conference: "An Aging Planet, An Expanding Population and A Sustainable Future: Changing Attidues and Values," sponsored by the Center for Public Service, Institute for Applied Sciences and by the Environmental Alliance for Senior Involvement, University of North Texas, May 28, 1999 (INVITED POSTER PRESENTATION).

A. P. Marchand, K. A. Kumar, A. S. McKim, S. Alihodzic, H.-S. Chong, K. Mlinaric-Majerski, G. Kragol, and T. Sumanovac, "Novel Cage-Annulated Crown Ethers, Cryptands, and Molecular Boxes: A New Class of Ionophores for Selective Ion Complexation," 8th Lodz-Lyon Seminar Series, Mazury Poland, May 25-30, 1999, (INVITED - PLENARY LECTURE).

A. P. Marchand and H.-S. Chong, "Syntheses and Alkali Metal Picrate Extraction Capabilities of Novel, CageFunctionalized, Pyridine-Containing Crown Ethers and Cryptands," 32nd Annual ACS Meeting-in-Miniature, University of Texas at Dallas, Richardson, TX, April 16, 1999, (CONTRIBUTED - ORAL PRESENTATION). 
A. P. Marchand and H.-S. Chong, "Syntheses and Alkali Metal Picrate Extraction Capabilities of Novel, CageFunctionalized, Pyridine-Containing Crown Ethers and Cryptands," 2nd Annual Graduate Research/ Performance Fair, University of North Texas, Denton, TX, April 13-14, 1999, (CONTRIBUTED - POSTER PRESENTATION).

R. A. Sachleben, B. A. Moyer, J. C. Bryan, and A. P. Marchand, "Ion Recognition Approach to Volume Reduction of Alkaline Tank Waste by Separation and Recycle of Sodium Hydroxide and Sodium Nitrate," EMSP Tanks Focus Area (TFA) Workshop, Richland, WA, Nov. 17-18, 1998. (INVITED ORAL PRESENTATION). 